\title{
Malatya Beş Konaklar Etnografya Müzesi’nde Bulunan Bir Gurup Şifa Tası
}

\author{
Ercan ÇALIŞ \\ Van Yüzüncü Y1l Üniversitesi, Edebiyat Fakültesi, Sanat Tarihi Bölümü, Van \\ ercancalis6547@gmail.com \\ ORCID ID: https://orcid.org/0000-0003-1359-4533
}

\begin{tabular}{lrr} 
Araştırma Makalesi & DOI: 10.31592/aeusbed.593610 \\
\hline Geliş tarihi: 18.07 .2019 & Revize Tarihi: 28.11 .2019 & Kabul tarihi: 28.11 .2019
\end{tabular}

\section{Atıf Bilgisi}

Çalış, E. (2019). Malatya Beş Konaklar Etnografya Müzesi'nde bulunan bir gurup şifa tası. Ahi Evran Üniversitesi Sosyal Bilimler Enstitüsü Dergisi, 5(2), 312-331.

\section{ÖZ}

İnsanoğlunun tarih sahnesinde belirdiği günden bu yana dinler, insan yaşamını biçimlendirdiği bilinmektedir. Dinlere bağlı gelișen inançlar tapınaklar, mezar anıtları ve çok sayıda el sanatları ürünlerinin açığa çıkmasında önemli bir rol oynamıştır. Ortaya çıkan tüm bu öğeler, toplumlara ait kimliklerinin önemli unsurlardan birini oluşturmaktadır. Ruhen ve bedenen tarih boyunca insanoğlu pek çok şeyden şifa bulmak amacıyla medet aramıştır. Geçmişten günümüze dek insanlar şifa bulmak için genellikle iki arayış içine girmişlerdir. Bunlardan birisi tıbbi yollar iken diğeri ise tüm toplumların ortak bir belirtisi olarak her toplumda görülen din ve bu kapsamda süre gelen kutsal kitaplardır. Dine bağlı olarak gelişen şifa tasları, insanlar tarafından iki farklı şekilde şifalanma ihtiyacını gidermek amacıyla kullanmıştır. Bunlardan birisi bedene ait hastalıklardan kurtulmak, diğeri ruhsal sıkıntılardan ayıklanmak içindir. Şifa tasları, Türklerin İslamiyet'i kabul etmesiyle Anadolu kültürünün önemli bir parçası haline gelen inanç geleneklerinin günümüze aktarılmasında, önemli bir etnografik eser grubudur. Bu bağlamda çalışmanın esasını oluşturan Malatya Beşkonaklar Etnografya Müzesi'nde bulunan bir grup tas ele alınarak, ait oldukları dönemin inanç geleneklerine bağlı şifa arama anlayış1 ile sanat pratikleri irdelenmeye çalışılmıștır.

Anahtar Kelimeler: Malatya, müze, el sanatları, İslamiyet, şifa tasları.

\section{A Group of Healing Bowls in the Malatya Beş Konaklar Ethnography Museum}

\begin{abstract}
Religions have been known to shape human life since the day when mankind appeared on the stage of history. Beliefs built upon religions have played an important role in the emergence of temples, grave monuments and numerous handicraft products. All these emergent elements constitutes one of the important factors of the identities of societies. Throughout history, human beings have hoped for help from many things, spiritually and physically, in order to heal. From past to present, people have sought mainly two ways for healing. One of them is the medical path, while the other is the religion which is observed in every society as a common symptom of all societies and the sacred books which subsist within this framework. Healing bowls developed based on religion had been used by people to satisfy the need for healing in two different ways. One of them is for getting rid of the diseases of the body and the other is for recovering from mental problems. Healing bowls are an important group of ethnographic works in the transfer of belief traditions, which became an important part of Anatolian culture with the acceptance of Islam by the Turks, to the present day. In this context, by examining a group of bowl in Malatya Beşkonaklar Ethnography Museum which forms the basis of the present study, the art practices were tried to be examined with the understanding of healing quest based on the belief traditions of the period they belonged to.
\end{abstract}

Keywords: Malatya, museum, handicrafts, Islam, healing bowls.

\section{Giriş}

Kayısı diyarı olarak bilinen Malatya, çağlar boyunca çok sayıda medeniyete ev sahipliği yapmış kadim bir Anadolu yöresidir. Akadlar, Hititler, Romalılar, Bizanslılar ile Selçuklu ve Osmanlılar bu bölgeye hükmetmiş önemli medeniyetlerin başında gelmektedir. Malatya, Anadolu'da coğrafik olarak jeopolitik bir konuma sahiptir. Kent Anadolu'nun doğu ve batısı ile kuzey ve güneyinin merkezinde yer alan önemli bir geçiş güzergâhında yer almaktadır. Öte yandan Türkiye'de ayrılan bölgeler açısından bakıldığında kent, Doğu Anadolu Bölgesi'nin Yukarı Fırat havzasında bulunmaktadır. Malatya yöresinin tarihi, kazılarda ele geçirilen verilerden anlaşılıyor ki tarih öncesi çağlara kadar gitmektedir. Yörede taş devrinde yaşadıklarına dair bulunan bazı buluntular bunu doğrulamaktadır. "Malatya Caferhöyük, Anadolu'da seramik öncesi dönemi temsil eden Diyarbakır Çayönü ile birlikte iki önemli yerleşkedir" (Bingöl, 1999, s. 13). Caferhöyük kazılarında çok sayıda çeşit zenginliğe sahip buluntu ele geçirilmiştir. Bunun yanı sıra, Değirmentepe, İmamoğlu, Pirot ve Köserbaba Höyükleri ile Battalgazi 
(Eski Malatya) yakınındaki Arslan Tepe'de yapılan kazılarda da çok sayıda yerleşik hayatın belirtilerine dair buluntular ele geçirilmiştir. Bu buluntulardan yola çıkarak bu dönemde yörede yaşamış insanın paleolitik yaşam tarzından Neolitik yaşam tarzına geçiş yaptığını göstermektedir. "Taş devri kültürüne ait izler taşıyan buluntularla birlikte Malatya yöresinin tarihi 8000 yıllık bir geçmişe sahip olduğunu göstermektedir" (Akçadağ, 2016, s. 189). Yörede Kalkolitik döneme de ait çok sayıda izleri görmek mümkündür. Değirmentepe ile bugünkü Bahçebaş1 (Orduzu) köyü yakınındaki Arslantepe höyükleri, Kalkolotik döneme ait önemli yerleşkelerdir. Bu dönemde yörede tarımda ilerlemeler kat edilirken, maden işçiliğinde de önemli gelişmeler yaşanmıştır. Arslantepe Höyüğü'nde M.Ö. 3000 yıllarına tarihlenen bir tapınakta, çok sayıda mühür baskı ve metal eserler ele geçirilmiştir.

Medeniyetlerin beşiklerinden biri olan Malatya, tarih öncesi dönemlere giden yerleşim yerlerindeki yapılan kazılarla ele geçirilen buluntular ile yörede vatandaşlar tarafindan bir şekilde edinilen eserler, ağırlıklı olarak yörede bulunan müzelerde sergilenmektedir. Etnografik eserlerin sergilendiği ve bu çalışmanın da esasını oluşturan şifa tasları, Malatya Beş Konaklar Etnografya Müzesi'nde bulunmaktadır. Beş Konaklar Müzesi, orijinalinde Malatya'nın geleneksel sivil mimari yapılardan birisiyken, Kültür Varlıkları ve Müzeler Genel Müdürlüğünün 2015 yılında aldığı bir kararla müze olarak hizmet verdirmesini sağlamıştır. Kerpiçten ve iki katlı olarak tasarlanmış müze, kanatlı kapıdan hayat veya taşlık olarak adlandırılan sofaya girilir. Sofa bölümü diğer oturma alanlarına göre daha serin ve havadar olduğu için genellikle yaz aylarında kullanılırdı. Müze olduktan sonra binanın işlevsel özellikleri değişmiştir. Çalışmanın kapsamında yer alan şifa tasları ve diğer etnografik eserler üst katta bulunan odalarda sergilenmektedir. Öte yandan üst katta yer alan bazı odaların içi geleneksel Malatya Evi şeklinde canlandırılmıştır. Binanın avlusunda ise Selçuklu ve Osmanlı dönemine ait taş eserler sergilenmektedir.

Şifa halk arasında bir hastalı̆̆ tedavi etme, hastayı iyileştirme gibi manalarda kullanıldığı bilinmektedir. "Arapça kökenli bir kelime olan şifa, maraz, tedavi ve inşirak gibi anlamları da kapsamakla beraber, hastalıklardan kurtulma ve iyi olma gibi anlamlarda kullanılmaktadır" (Develioğlu, 1998, s. 997). Tarih boyunca insanlar şifa bulmak için genellikle iki arayış içine girmişlerdir. Bunlar tıbbı yollar ile din ve dine bağlı olarak kutsal kitaplardır. Dile getirilen bu iki arayış dışında da insanlar, kısmen de olsa farklı yöntemlerle de şifa arayışı içine girdikleri görülür. Bunlar arasında dikkat çekenlerden birisi değerli taşlardır. Değerli taşlar, keşifleriyle beraber toplumları farklı yönlerle etkilediği bilinmektedir. Doğada az bulunması, parlaklığı ve sertliği gibi bazı özelliklerinin de etkisiyle yeri gelmiş koruyucu bir tılsım olarak kabul edilmiş, yeri gelmiş çeşitli hastalıkları tedavi edileceğine inanılarak kullanılmıştır. Bu amaçlarla kullanılan zümrüt ve safir taşı dikkat çekicidir. "Zümrüt taşının dizanteriyi iyileştirdiğine ve kötü ruhları uzaklaştırdığına inanılmış, dahası zümrüdün yutulduğunda pek çok hastalığa iyi geldiğini söylemişlerdir” (Portakal, 2000, s. 135).

"Zümrüt taşında olduğu gibi safir taşının da başta göz hastalıkları olmak üzere birçok hastalığa iyi geldiğini dile getirmişlerdir" (Portakal, 2000, ss. 133-134). Bunun yanı sıra tılsım, sihir, büyü, uğur, nazara karşı korunma hissi gibi amaçlarla da insanlar birtakım takıları üzerlerinde taşımışlardır. Anlaşılmaktadır ki insanoğlu en ilkel döneminden beri yukarda anlatılan bu tür hususlarla mücadelede sürekli bir arayış içinde olmuştur.

Ele alınan çalışmanın esasını oluşturan şifa tasları üzerinde yazıtlardan, bu dönemde yaşamış insanların şifayı kutsal kitaplara temellendirerek aradığı gerçeğidir. Kutsal kitaplardan önce Türklerde şifayı arama istemi mitlerde geçmektedir. Türklerin eski dini Şamanizm'de Şaman ya da Kam olarak bilinen din adamları sihir ve büyülerle çeşitli hastalıkları tedavi etme yönelimlerde bulunurlardı. "Şamanlı̆̆ın kökleri Türklerin İslamiyet'i kabulüyle beraber Türk insanı tarafindan kabul görmeyen büyü, sinir ve tabiplik gibi ilkel kültürel öğelere ve mistisizme temellendirilmekteydi” (Tali, 2013, s. 2120).

Türk İslam döneminde kutsal kitapla birlikte mücadele ve korunma hissiyatıyla beraber şifa kapları, en çok tercih edilenlerin başında gelmiştir. Bu taslara en yakın örnekler, "İslamiyet'ten önce Aramiler döneminde görülmektedir" (Gedük, 2017, s. 358). Aynı zamanda "sihir, büyü ve şifa arama gelenekleri de M.Ö. 2000 yılının son çeyreğine kadar Aramilere gitmektedir” (Tali, 2013, s. 2122). 
Anadolu'da üretilmiş şifa tasları Türk hamamlarında kullanılmış taslara benzemektedir. Bunun yanı sıra Gordiyon'da bulunan Frig taslarıyla da çok benzeşmektedir. "Bu taslar, kenar ve göbek tasarımlarıyla birbirine çok benzerken, şifa taslarının iç süsleme programında bitkisel ve diğer süslemelerin yerine ağırlıklı olarak ayetlerle bezenmiş olmalarıyla diğer taslardan ayrılır” (Masaracı, 2007, s. 156).

İslamiyetle beraber dünyadaki diğer Müslümanlar gibi Türkler de tıbbi arayışlar dışında kalan şifa arayışlarını kutsal kitabımız olan Kur'an-Kerim'de aramışlardır. Zira Kur'an-Kerim'in kendisi de şifa ile ilgili ayetlerinden dolayı şifa kaynağı olarak bilinmektedir. Özellikle de Kur'an insanın ruhsal dünyasının iyileşmesi noktasında, daha çok şifa ettiği kabul görmektedir. Ahlaki hastalıklarla beraber zihinsel ve psikolojik rahatsızlıkların tedavisinde günümüze dek Kur'an, bir şifa kaynağı olduğu bilinmektedir. Kur'an'da şifa kelimesi 6 yerde geçtiğinden dolayı şifayla ilgili 6 ayetten söz edilebilir. Ayetlerin özellikle art arda okunduğunda şifa anlamında daha verimli ve etkili olduğu âlimlerce dile getirilmektedir. Öte yandan aslında Allah'tan gelen Kur'an-Kerim'in bizzat kendisi bir şifadır. Zira ruhsal bozukluklar dışında kalan tıbbi yöntem ve müdahaleler sonucunda da insanların bu uygulamalar esnasında ve sonucunda dua ederek Allah'tan şifa beklediği bilinmektedir. Kur'an inanan insanı hastalıklardan arındırarak sağlığına kavuşturmaya yardımcı olduğu bilinmektedir.

Şifa bulmak amaciyla insanlar Kutsal kitaplarda geçen ayetleri çeşitli araçlar kullanarak, insanların istifade etmesini sağlamaya çalışmışlardır. Şifa tasları da bu araçlar arasında yer alan önemli bir etnografik eserdir. Üzerlerinde çeşitli ayet, dua ve tılsım işaretleri taşıyan bu taslar, içine konulan suyu içen insan ve hayvanların şifa bularak sağlıklarına kavuştuğu söylenmektedir. Zira şifa taslarına konulan suyun üflenmesi, bu sudan içilmesi ve yıkanılması, İslamiyet'in ilk yıllarına kadar uzandığı bilinmektedir.

Şifa kapları kısmen seramik ve porselenden üretilmekle beraber müzelerin etnografik salonlarına bakıldığında ağırlıklı olarak pirinç, bakır, bronz gibi madenlerden yapıldığı anlaşılmaktadır. $\mathrm{Bu}$ tasların hem iç hem de dış yüzeyi dualar, ayetler ve hadislerle bezenmiştir. Bu yazıların araları genellikle kazıma tekniğinde geometrik ve bitkisel motiflerle doldurulmuştur. Çalışmaya dâhil edilen ve Osmanlı dönemine tarihlenen taslar, Osmanlı öncesi Türk İslam dönemlerinde olduğu gibi bu dönemde de şifa arayışları devam ettiği, çalışmaya konu olan eserlerden anlaşılmıştır. İslamiyet'in ilk döneminde şifa taslarına ait ilk örnek, XII. yy.'da Büyük Selçukluların Haleb Atabeyi Sultân elMelike'l-'âdil Mahmûd ibn Zengî'ye hazırlanan ve üzerine diğer dini yazılarla beraber "Bu kutsanmış kap her tür zehir içindir. İçerisinde kanıtlanmış kullanımlar bir araya getirilmiştir. Bunlar; yılan sokması, akrep ve ateş, hamile kadın, atın toprak yemekten kaynaklanan karın ağrısı, baş ağrısı ve kolit, migren ve çarpıntı, karaciğere bağlı ateş, kanama, göğüs arası, göz ve görme, nazar, katarkt, yel vurması, ruhları kaçırmak, büyüden kurtarmak ve tüm hastalık ve acılardır." tıbbi tedavi amaçlı yazısı işlenmiş tas'tır (Perk-Paksoy, 2011, s. 9). Bunun yanı sıra, Orta Anadolu ve Doğu Anadolu'da yaygın olarak kadınlar tarafından kullanılmış şifa tasları yine pek çok hastalıktan kurtulmak amacıyla kullanıldığı bilinmektedir. Dr. Ercan Topçu "Şifa Taslarının Türk Tıp folklorundaki Yeri" adla makalesinde şu şekilde değinmiştir: "Hüzün ve sıkınt1, vesvese, kalp çarpıntısı, uykuda korkma, can sıkıntısı, gam ve kederden kurtulmak için, nazar değmesine karşı, halk arasında ağız çarpılması denen yüz felçlerinde, ruhsal iyileşme moral ve motivasyonun ön planda olduğu durumlarda etkili olarak uygulanmıştır. Bazen akrep, yılan, zehirli böcek sokmalarına karşı halkın şerbetleme diye adlandırdığı usulde kullanılmıştır. Anadolu'da halk hekimliğinde çeşitli rahatsızlıklarda şifa tasları kullanıldığı gibi doğum, göbek kesme, ad verme, loğusalık, ilk saç kesimi, kırık çıkarma, diş çıkarma, sünnet, askere gitme, sözlenme, nişanlanma, evlenme, gerdek ve ölüm gibi zamanlarda şifa taslarından sular içilmiş, ikram edilmiş ve üzerine serpilmiştir. Bir de herhangi bir işle ilgili sonuç kötü olduğunda, içinden çıkılmaz bir durum olup bunalım veya kriz olduğunda da insanlar bir yerde çaresiz kaldıklarında yüce Allah'tan yardım istemişler, bunu yaparken de şifa taslarını kullanmışlardır.” demektedir (Topçu, 2010, s. 91).

Şifa arayışlarının devam ettiği bu dönemde tasların üzerinde daha çok ayet, hadis ve dualar yazılmış, bunun yanında yer yer geometrik ve bitkisel süslemelerle tasların yüzeyleri bezenmiştir. Diğer sanat dallarında olduğu gibi bu dönemde Osmanlılar, maden sanatında da en parlak dönemini yaşamıştır. Madeni eserlerde kullanılan malzeme ve uygulanan teknikler kendi içerisinde apayrı bir öneme sahiptir. Uygulanan yapım ve süsleme teknikleri şifa amaçlı yapılmış olan taslarda da kendini göstermiştir. 
"Selçuklu ve Memluk etkilerinin devamını yansıtan dönemin süslemeli şifa taslarında, üzerlerinde yer alan ayet ve dualar içlerine konulan su ile birlikte şifa bulmak amacı ile hastalara aktarılmıştır" (Tali, 2013, s. 2122).

\section{Yöntem}

Çalışmaya dâhil edilen bu kapların seçilmesinde öncelikle bu alanda yapılan araştırmaların yetersiz oluşudur. Şifa tasları ile ilgili yapılan bilimsel araştırmaların yetersizliği bu konuya olan yönelimi doğurmuştur. Söz konusu müzeden ilgili izinler alındıktan sonra müzede muhafaza edilen tüm şifa tasları çalışma programına dâhil edildi. Toplam 14 adetten oluşan şifa tası grubu form, malzeme ve süsleme kompozisyonları dikkate alınarak birbirinden farklı oldukları tespit edilen 10 adet kap değerlendirilmeye alınd.

Eserler tek tek incelenmeye alınarak sanatsal özellikleri gün 1şığına çıkarılmaya çalışıldı. Bu çalışmalarda ilk önce yapımında kullanılan malzemeyle beraber hangi yapım ve süsleme teknikleriyle yapıldıkları tespit edildi. Eserlerin ölçüleri de alındıktan sonra fotoğraflanma işlemine geçildi. Daha sonra süslenme programları ile beraber üzerlerinde yer alan kutsal yazıların çözümlemesine başlandı. Ardından eserlerin çizimleri de yapılarak, tanıtımları yapıldı. Eserlere ait sanat özellikleri de yapıldıktan sonra Anadolu'nun farklı bölgelerinde üretilen ve farklı müzelerde yer alan benzer taslarla karşılaştırmalara gidildi. Değerlendirme süresi tamamlanan eserlerle ilgili bir sonuca varılarak, şifa tasların Türk ve İslam dünyasındaki serüveni ile günümüz açısından taşıdığı anlam ve değer vurgulanmaya çalış1ld.

\section{Bulgular}

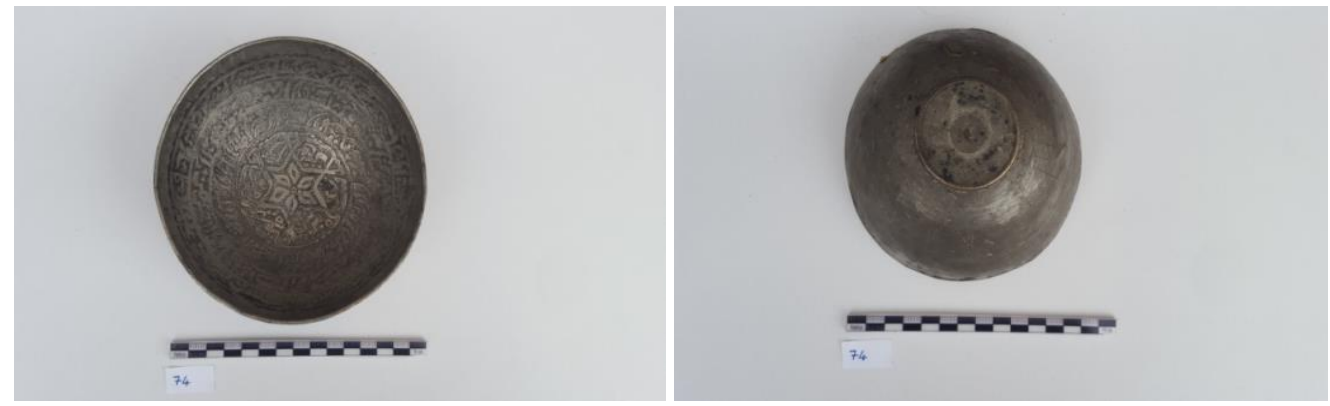

Fotoğraf 1a-b. Bakır Şifa Tası, Osmanlı (19 yy.), Envanter no: 74, Ağız Çapı: 13,7 cm, Dip Çapı: 4,9 cm, Yükseklik: $5,5 \mathrm{~cm}$.

Küt dudaklı eser, geniş ve dik karınlıdır (Bkz. Foto. 1a-b; Çizim 1). Hafif bombeli dipli kap k1sa kaideli ve hamam tası formludur.

Eserin içi yüzünün ağız kısmında dar bir friz içinde belirli aralıklarla Hz. Ebubekir, Hz. Ömer, Hz. Osman ve Hz. Ali' den oluşan 4 halifenin isimleri yazılmıştır. Tasın iç karın kısmının yüzeyinde 3 adet bordür içinde ayet Âyete'l-Kürsî suresinin tamamı işlenmiştir. Dipte ortada Arapça Ashâb-1 Kehf yazısı yer almaktadır. Yazının merkezinde 6 yapraklı bir çiçek motifini çevreleyen 6 kollu yıldız motifi bulunmaktadır. Dışta karın yüzeyi dahil kabın tümünün üzerinde herhangi bir süslemeye yer verilmemiştir. 

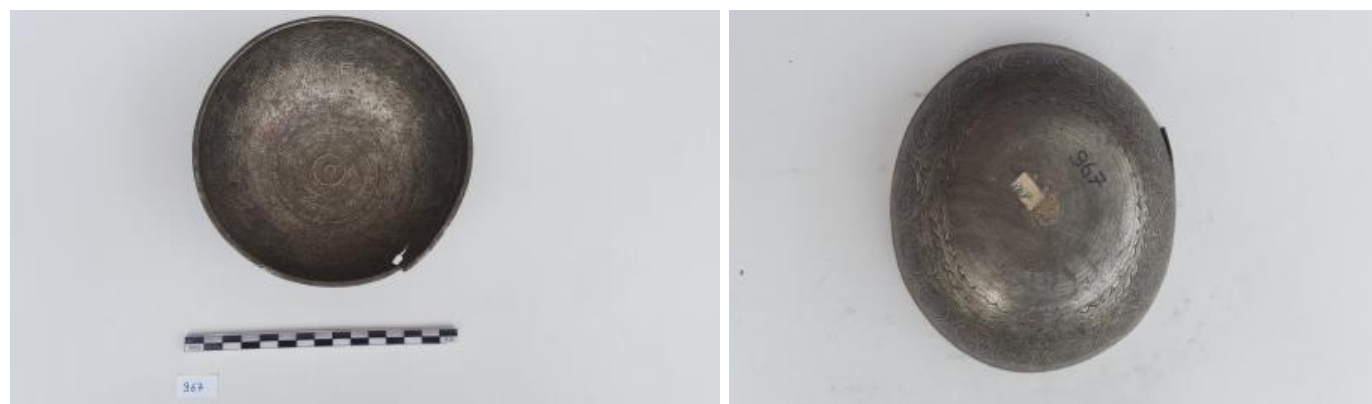

Fotoğraf 2a-b. Bakır Şifa Tası, Osmanlı (17-18 yy.), Envanter no: 967, Ağız Çapı: 14 cm, Dip Çapı: 7,5 cm, Yükseklik: $5 \mathrm{~cm}$

Döküm yapım tekniğindeki dipli ve kaidesiz eser, geniş ağızlı ve dik karınlıdır. Hafif bombeli kap, hamam tası formludur (Bkz. Foto. 2a-b; Çizim 2).

İç gövdenin yüzeyi iç içe geçmiş halka şeklinde bordürlere ayrılmıştır. Ağız kısmında bulunan dar bordürde tekrar şeklinde yazılmış İhlas ve Kâfirun suresi bulunmaktadır. Hakim bordür karın kısmında bulunmaktadır. Diğerlerinden oldukça geniş olan bu bordürün içine 13 adet uçları yukarıya doğru kıvrık, yılan başı şeklinde damla motifi art arda sıralanmıştır. Bu motiflerin içine İhlas, Nas ve Felak Suresinin tamamı işlenmiştir. Damla motiflerinin arasındaki boşluklarda da Yâ Allâh, Yâ Kerîm, Yâ Rabb, Yâ Hannân (merhamet eden) gibi Allâh'ın güzel isimlerinden bazılarına yer verilmiştir. İç gövdenin karın bölgesinde bulunan geniş bordürün altındaki dar bordürde İhlas suresi işlenmiştir. Hemen bu bordürün altında kazıma tekniğinde basit süslemelerden oluşan bir bordür daha yer almaktadır. Arkasından gelen iki dar bordürdeki yazılar okunamazken, dipteki geniş bordürün içine erRahman Suresi kazınmıştır.

Dış yüzün ağız kısmında dar bir bordür içine İhlas Suresi, Nas Suresi ve Saf Suresinin 13. ayetinin bir kısmı olan "nasrun minallâhi ve fethun karîbun": "Yardım ve zafer Allah'tan ve pek yakın bir fetih" yazıları işlenmişsir. Dış Karın kısmındaki geniş bordür içerisinde, iç kısımda bulunan damla motifleriyle bezelidir. Ancak iç kısımda 13 tane damla şeklindeki motife yer verilirken, dış kısımda 16 adet bulunmaktadır. Bu motiflerin içi 3 satır halinde Arapça yazılarla dolgulanmıştır. İçlerinde Yâ Rahman, Yâ Rab, Yâ Allah, Yâ Kerîm, Yâ Hannân, Yâ Burhan, Yâ Settar, yâ Rahîm, Saf Suresinin 13. ayetin bir kısmı olan "nasrun minallâhi ve fethun karîbun" ile İhlas ve Felak Suresinin bir kısmı yazılmaktadır. Bunun yanı sıra damla motfilerinden birinin içindeki alt ve üst satırında İhlas suresinin ilk ayeti, orta satırda ise er-rahman yazısı mevcuttur. Öte yandan kabın dip kısmının ortası sade tutulmuşken, çevresinde kazıma tekniğinde "SSS" harflerinden oluşan bir friz dolaşmaktadır.
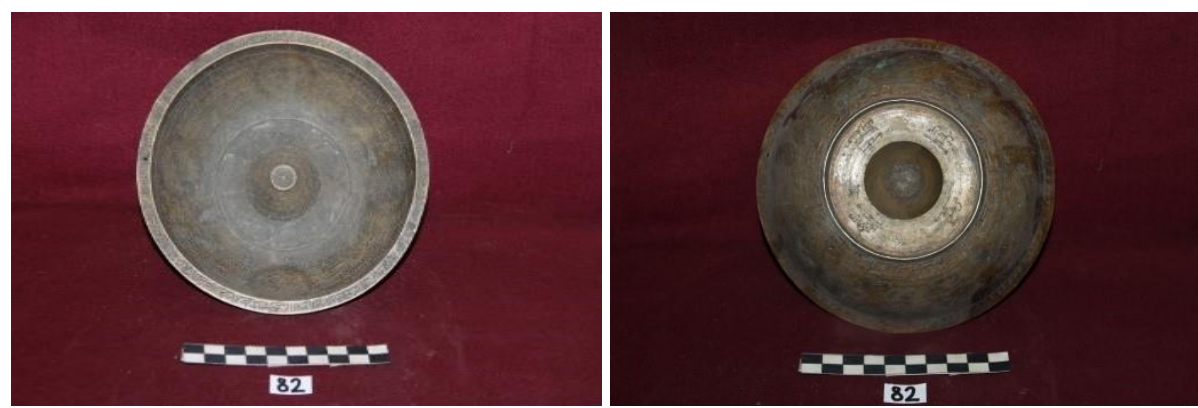

Fotoğraf 3a-b. Bronz Şifa Tası, Osmanlı (18 yy.), Envanter no: 82, Ağız Çapı: 2,0 cm, Dip Çapı: 4,9 cm, Yükseklik: $4,5 \mathrm{~cm}$

Döküm yapım tekniğinde oluşturulmuş eser, yayvan yarım küre şeklinde, ortası göbekli ve altı kısa kaidelidir (Bkz. Foto. 3a-b; Çizim 3-4). Dudaklı tasın dibinde bulunan göbek yukarıya doğru konik çatılıdır. Oturtmalık kısmında ise taban içe doğru basık formdadır. 
İç yüzeyinde dudaktan başlamak üzere ağız kısmıyla devam eden ve karın kısmını da çevreleyen Yasin suresinin bir kısmı yer almaktadır. Kabın karın yüzeyine işlenmiş Yasin suresindeki bir bölüm ayrıca 4 adet dairesel madalyon içerisine yerleştirilmiştir. Karın kısmının altında yer alan ve göbek bölümünü dıştan çevreleyen geniş kuşakta baklava motiflerinin içerisinde birer papatya motifi ile aralarda stilize edilmiş tılsıma yer verilmiştir. Göbekli taslar grubuna giren eserin göbek üstündeki düz dairesel alanda, çarkıfelek motifi yer almaktadır. Göbek yan yüzeyleri 3 kartuşa ayrılarak, Arapça besmele, peygambere salavat yazılarının yanı sıra Allâhümme Sallî Alâ Ali Mustafa Muhammed ElMurtaza Ali bin Hüseyin Muhammed bin Ali Cafer bin Muhammed Musa bin Cafer Ali Musa Muhammed bin Ali Hüseyin yazısı okunabildi. Eserde meydana gelen oksitlenmeler ile tahribattan dolayı bazı yazılar okunamamıştır.

İç yüzeyinde olduğu gibi arka yüzeyinde de yoğun süslemeleri görmek mümkündür. Dış yüzde, ağız kısmında kazıma tekniğinde basit süslemeler mevcuttur. Ağız kenarının altında besmele ile başlayan Yasin suresinin bir kısmı yazılıdır. Dış karın kısmında geniş bir bant içinde Fatiha ve İhlas surelerinden bir kısım ayetlerin yazıldığı bir dizi madalyonlara yer verilmiştir. Eser üzerindeki tahriplerden dolayı silikleşmiş yazıların bir kısmı okunamamıştır. Kabın dış dibinde Yasin ve Kul e'uzü, Kul Hüvellâhü Süresi ile Elhamdülillah surelerinin isimlerine yer verilmiştir. Burada Kul e'uzü suresiyle olasılıkla fazla yer kaplayacağı dikkate alınarak hem Felak hem de Nas surelerine atıfta bulunulmuştur.

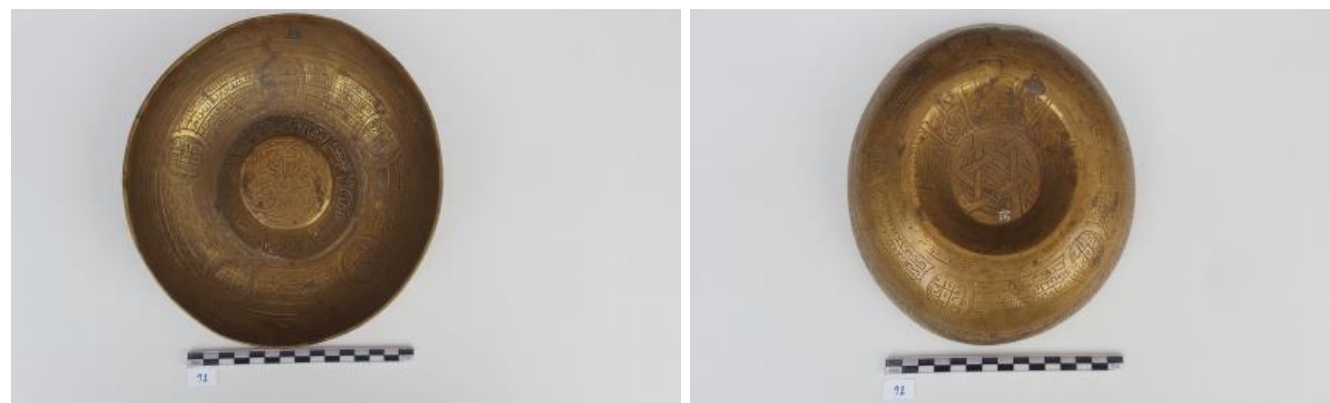

Fotoğraf 4a-b. Pirinç Şifa Tası, Osmanlı (17-18 yy.), Envanter no: 91, Ağız Çapı: 19,5 cm, Dip Çapı: 10 cm, Yükseklik: $5 \mathrm{~cm}$

Göbekli taslar arasında yer alan bir diğer eser yarım küre şekilli ve kaidesizdir (Bkz. Foto. 4ab; Çizim 5). Tasın iç yüzeyi yayvan ve düz ağızlıdır. Tasın iç dip kısmında bulunan göbek kesik konik şeklindedir. Tasın dış kısmındaki taban kısmı içe doğru basık formdadır. Dudak kısmı yoktur.

İç yüzeydeki ağız kısmında 2 satır halinde Allah isimlerinin yazıldığı 1 art arda sıralanmış toplamda 34 adet sivri kemerli nişle bezenmiştir. Bu kısmın altında fatiha suresi düz olarak dar bir bordüre kazınmıştır. Karın kısmındaki geniş bir bant içinde satır ve sütun şeklinde kare alanlara bölünmüş bölümlerin içerisine yazılmış Arapça harflerden oluşan vekfler, 5 adet dairesel madalyon içerisine alınmıştır. Bunun dışında dairesel madalyonların aralarına denk gelecek şekilde dört satır halinde, Fatiha, İhlas, Felak ve Nas sureleri yazılmıştır. İç karındaki geniş bordürün hemen altında yer alan dar bordürün içi kazımalarla meydana getirilmiş basit bezekler mevcuttur.

Kesik konik şeklindeki göbeğin üst yüzeyi "Kul kullun ya'melü 'ala şakiletihi ferabbukum $a^{\prime}$ lemü bimen hüve ehdâ sebıla(n) ${ }^{1}$ : De ki: "Herkes kendi yapısına uygun işler görür. Rabbiniz, en doğru yolda olanı daha iyi bilir." ibaresi yer almaktadır. Göbeğin yan yüzeylerinde Bismillahi'ş-şafi (Şafi: Hastaya şifa veren, Allâh'ın güzel isimlerindendir) yazı tekrarından oluşmaktadır.

Eserin dış yüzünün ağız kısmı sade bırakılmışken, hemen altında Âyete'l-Kürsî suresinin bir kısmının yazıldığı bir bordür bulunmaktadır. Dış karın kısmında dar bir kuşağın içinde basit süslemelerden oluşan kazımalar mevcuttur. Hemen altında karın kısmının en geniş frizi içinde Bakara suresinin son ayetleri 4'er satırlar halinde yazılmıştır. Bu satırların ortalarında satır ve sütun şeklinde kare alanlara bölünmüş bölümlerin içerisine yazılmış Arapça harflerden oluşan vefkler, 5 adet dairesel

\footnotetext{
${ }^{1}$ İsra Suresi, 84. Ayet.
} 
madalyon içerisine alınmıştır. İçe doğru basık olan bölümünün dış sınırını belirleyen dar frizin içine alınmış basit süslemelerden meydana gelmiş kazımalar işlenmiştir. Tabandaki konik yan yüzeylerde içinde grift bir karakterle yazılmış okunamayan bir Arapça yazısı yer alırken, iç kısımda ise mühr-ü Süleyman motifi yer almaktadır.

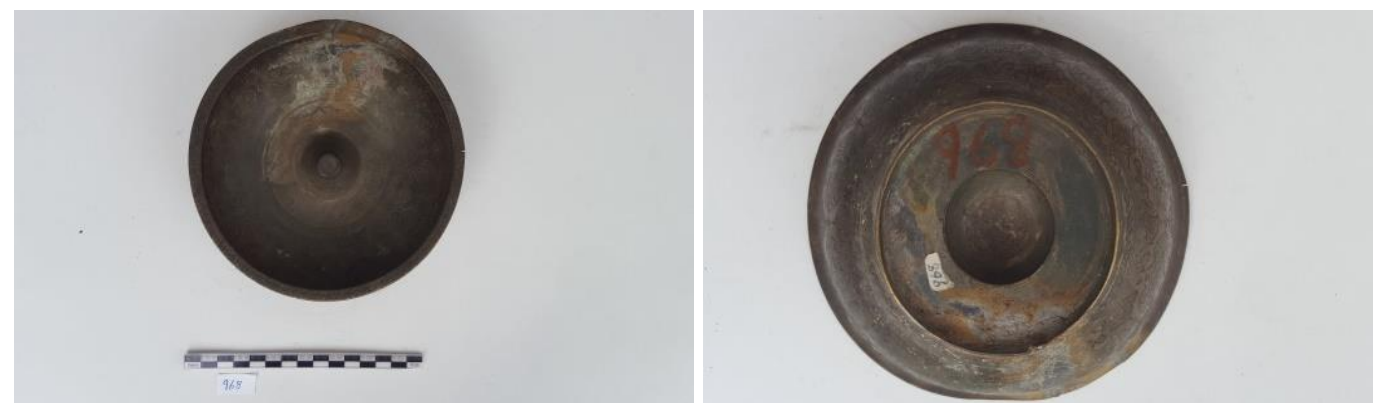

Fotoğraf 5a-b. Bronz Şifa Tası, Osmanlı (17-18 yy.), Env. no: 968, Ağız Çapı: 15 cm, Dip Çapı: 7,9 cm, Yükseklik: 4,5 cm

Döküm yapım tekniğindeki eser, yarım küre şekilli, yayvan, göbekli ve altı kısa kaidelidir (Bkz. Foto. 5a-b; Çizim 6). Küt dudaklı tasın dibinde bulunan göbek, yukarıya doğru konik çatılıdır. Oturtmalık kısmında ise taban içe doğru basık formdadır.

Dudağın üzerinde hafif etli bir hatla başlayan Âyete'l-Kürsî yazılıdır. İçte ağız kısmında bir bordür içinde eserdeki tahribattan dolayı okunamayan bir yazı mevcuttur. Hemen bu kısmın altında, iç karın bölgesinde geniş bir bordür yer almaktadır. Bu bordürde uçları stilize palmet motifleri' ${ }^{2}$ ile sonlanan art arda bir dizi stilize şemse ${ }^{3}$ motifleri sıralanmıştır. Şemselerin içinde Yâ Rahîm, Yâ Settar, Yâ Hannân şeklinde devam eden Allah'ın güzel isimlerinden bir kısmı okunabilmiştir. Eserdeki oksitlenmelere bağlı olarak silikleşmiş yazının bir kısmı okunamamıştır. Şemse motiflerinin arasında bir dizi stilize edilmiş baklava motifleri ile tahribattan dolayı tam çözülmemekle beraber olasılıkla Yâ Rab yazısı yer almaktadır. Karın bölgesindeki geniş bordürün hemen altında yer alan dar bordürün içi harf ve sayılarla doldurulmuştur. İç kısımda göbeğin dıştan çevresinde yer alan genişçe bordürün içinde 4 adet palmet motifi mevcuttur. Palmetlerin içinde 4 kare alanına ayrılmış birer baklava dilimi motifi mevcuttur. Palmetlerin araları tahribattan dolayı tam çözülmemekle beraber olasılıkla Yâ Rabb yazısı ile Yâ Kâdîü'l-hâcât (Ey herkesin dileğini yerine getiren), Yâ Kâfiye'l-muhimmât (Ey önemli ve gerekli şeyler ve işlere yeten) yazısına yer verilmiştir. Öte yandan göbek üzeri sade tutulmuşken, yan yüzeyleri 3 adet basit bezeklerden oluşan kazımalı bordürle doldurulmuştur.

Eserin dış yüzüne bakıldığında karın kısmındaki süsleme hâkimdir. Geniş bir friz içinde Yâ Kâdiye'l-hâcât, Yâ Rebbe'l Mahbut, Yâ Allah, Yâ Kâfiye'l-muhimmât, Yâ Rafî'e'l-derecât (Ey dereceleri, mertebeleri yücelten) ibareleri, uçları stilize palmet motifleri ile sonlandırılmış dilimli kartuşlar içine yazdırılmıştır. Bunlardan bir kısmı aşırı oksitlenmelere bağlı olarak gerçekleşen tahribattan dolayı okunamamıştır. Bu kartuşların arasındaki alt ve üst palmetlerin içine Yâ Rabb yazısı işlenmiştir. Karın kısmındaki geniş frizin hemen altında ince dar bir bordürün içinde stilize edilmiş zencirek şeklinde bir motif yer almaktadır. Tasın dıştan dip kısmı ve göbek girintisinin yan yüzeyi ile iç yüzeyi sade bırakılmıştır.

\footnotetext{
2 Palmet: Bir Sapın iki tarafında simetrik olarak sıralanmış uzunca yapraklardan oluşan üsluplaştırılmış bitkisel bezeme öğesi (Sözen-Tanyeli, 2014:236).

${ }^{3}$ Şemse: Bir daire ile ondan yayılan 1şınsal çizgilerden oluşan bezeme örgesi (Sözen-Tanyeli, 2014:289).
} 

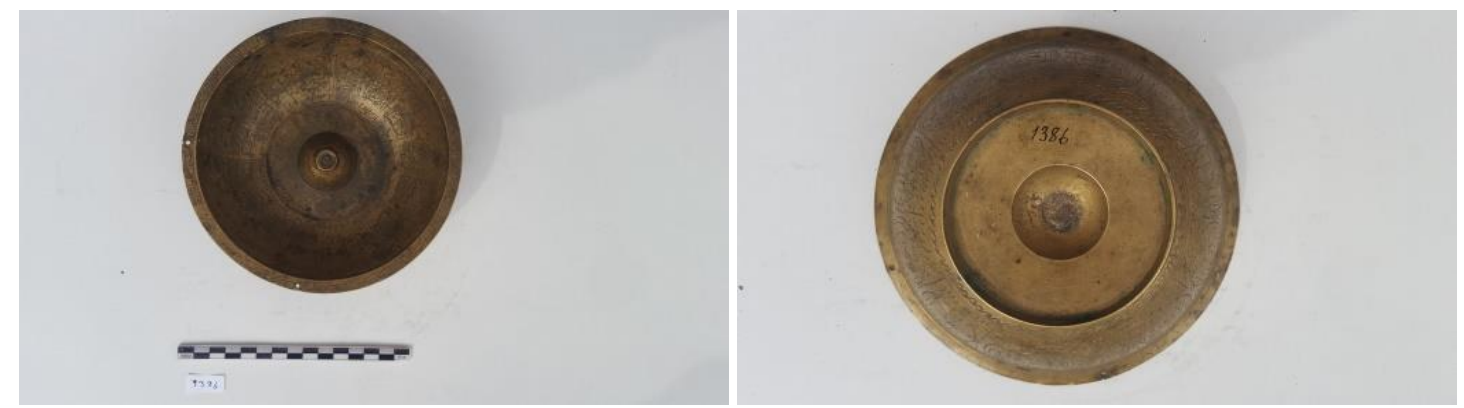

Fotoğraf 6a- $b$. Bronz Şifa Tası, Osmanlı (20 yy baş1), Envanter no: 1386, Ağız Çapı: 16 cm, Dip Çapı: 8 cm, Yükseklik: 4,8 cm

Döküm yapım tekniğinde oluşturulmuş eser, yarım küre şeklinde, ortası göbekli ve altı kısa kaidelidir (Bkz. Foto. 6a-b; Çizim 7, 8). Dudaklı tasın dibinde bulunan göbek, yukarıya doğru konik çatılıdır. Kabın oturtmalık bölümü taban içe doğru basık formdadır.

Kabın dudak kısmında Ayete'l-kürsi suresi yazılmaktadır. Bu bölümün altında bulunan ağız kenarında peygambere salavat ve peygambere bağli onun zamanında yaşayan Alahumme Salli Ala Muhammed Ali bin Hüseyin Muhammed bin Ali Cafer bin Muhammed Musa bin Cafer Ali Musa Muhammed bin Ali Hüseyin yazısıyla,12 imamdan bazıların isimleri okunabilmiştir. Eserdeki tahribattan dolayı bir kısım yazılar okunamamıştır. Dışa dönük bombeli olan iç karın kısmındaki geniş bordürde 16 adet kaş kemerli motif bulunmaktadır. Kemerler içerisinde 3 satır halinde yazılmış besmeleyle başlayan ihlas, felak ve nas surelerinin tamamı yazılmıştır. Karın kısmındaki geniş bordürün hemen altında, içine kazıma tekniğinde basit bezeklerin bulunduğu dar bir bordür daha vardır. Tasın dip kısmında göbek etrafinı çevreleyen bordür, içerisinde tekrar şeklinde Yar Rab yazılı olduğu 4 adet stilize palmet motifleri ile boşluklarda Yâ Veli, Yâ Cabbar, Yâ Kâfî (her şeye yeten) şeklinde Allah'ın güzel isimlerinden bazıları okunabilmektedir. Göbeğin yan yüzeyleri kazıma tekniğinde basit süslemelerden meydana gelmiş 3 adet bordürle çevrelenmiştir.

Dış yüzün ağız kenarı bir silme ile hareketlendirilmiş tasın, dış kısmında 2 dar 1 geniş olmak üzere 3 bordür yer almaktadır. Ağız kısmındaki 1. bordür ile karının altında bulunan 3. bordür kazıma tekniğinde basit bezeklerden oluşmaktadır. Dış karın kısmında bulunan geniş bordür içinde ise 12 adet dairesel madalyon mevcuttur. Bu madalyonların içi üç satır halinde tekrar şeklinde besmele ile başlayan "nasrun minallâhi ve fethun karîbun" yazısı yer almaktadır. Madalyonlar arasında kalan alt ve üst kısımlarda Yâ Rabb, yazısı devam etmektedir. Bunun yanı sıra, tasın dıştan dip yüzeyi ve göbek girintisinin iç ve yan yüzeyleri sade bırakılmıştır.
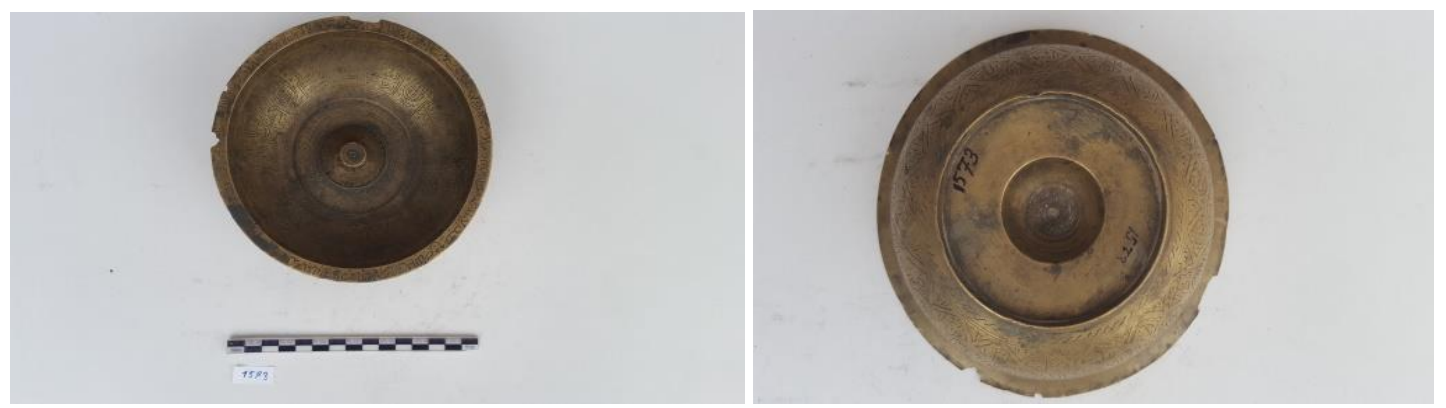

Fotoğraf 7a-b. Bronz Şifa Tası, Osmanlı (20. yy başı), Env. no: 1573, Ağız Çapı: 14,8 cm, Dip Çapı: 7,8 cm, Yükseklik: 4,5 cm

Döküm tekniğindeki eser, yarım küre şeklinde, konik göbeklidir. Tasın dip kısmı kısa kaideli ve süslemesizdir (Bkz. Foto. 7a-b; Çizim 9, 10). Dudaklı taslar grubundandır.

Dudakta Ayete'l-kürsi suresinin tamamı yazılıdır. Ağız kenarında Allâhümme salli ala Muhammedin ve Ali ve Fatıma ve'l-Hasan ve'l-Hüseyin ve Ela bin Hüseyin ve Muhammed bin ve Ali ve'l-Ca'fer bin Muhammed ve Musa bin Ca'fer ve Ali bin Musa Muhammed bin Ali ve bin Muhammed ve Hüseyin bin Ali Muhammed Mehdi şeklinde bir yazı yer almaktadır. İç karın kısmındaki geniş frizde 
simetrik bir şekilde yerleştirilmiş 8 adet dilimli kaş kemer mevcuttur. Kemerlerin içi 3 satır halinde besmeleyle başlayan İhlas, Felak ve Nas Sureleri ile Yasin suresinin 58. ayeti "Selamun kavlen min rabbi'r-rahim: Rahmeti kesintisiz Rabb'den söz selamdır" yazısı mevcuttur. Kemerlerle dönüşümlü bir şekilde friz içine yerleştirilmiş 8 adet damla motifi bulunmaktadır. Stilize damla motiflerini içlerinde Arapça sayılardan oluşan vefklere yer verilmiştir. Kaş kemerli motif ile damla motifinin arasında kalan bölümde uçları kıvrık küçük boyutlu yaprak motifi ile geometrik bir anlayışta basit şekilli kazımalar göze çarpmaktadır. Karın kısmındaki geniş frizin hemen altında kazıma tekniğinde "SSS"'lerden oluşan bir friz daha dolaşmaktadır. Göbek etrafını çevreleyen frizin içinde 4 adet stilize edilmiş palmet motifi kazılmıştır. Palmet motifinin içinde Arapça sayılardan oluşan vekfler mevcuttur. Palmet motiflerinin arasında da Yâ Rafî'e'l- hâcet, Yâ Kâfiye'l-muhimmât şeklinde yazılarla doldurulmuştur. Öte yandan Göbek üzeri sade bırakılmıştır. Göbeğin yan yüzeylerini dolanan 3 bordürün içi basit bezeklerle doldurulmuştur.

Dış yüzün ağız kenarı sade bırakılmış tasın, dış karın kısmında geniş bir friz bulunmaktadır. Frizin içinde stilize edilmiş birbirleriyle örgülü bir dizi palmet motifi yer almaktadır. Palmet motifinin içinde besmeleyle başlayan İhlas ve Nas surelerinin tamamı yazılıdır. Palmet motiflerinin araları geometrik bir anlayışta kazıma tekniğinde basit bezeklerle doldurulmuştur. Tasın dıştan dip kısmı ve göbek girintisinin iç ve yan yüzeyleri sade bırakılmıştır.
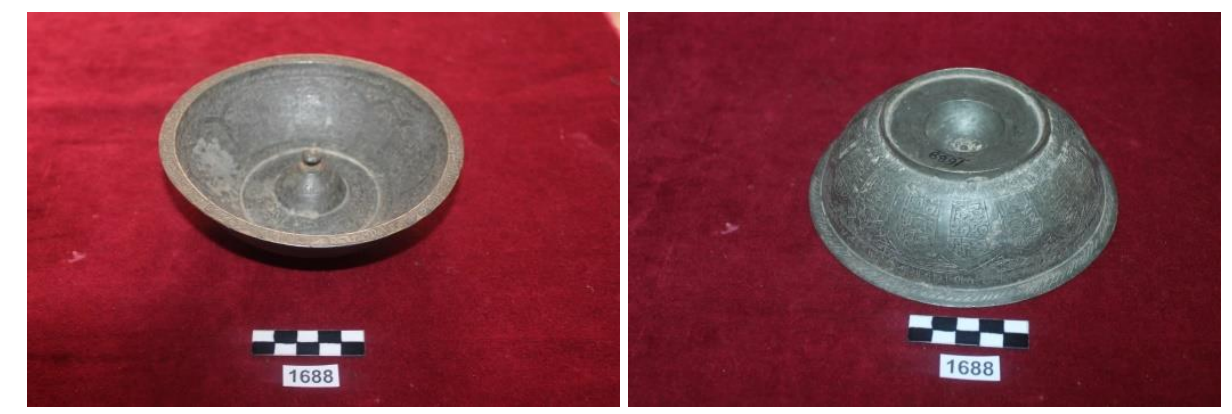

Fotoğraf $8 a-b$. Bronz Şifa Tası, Osmanlı (19 yy sonu, 20 yy baş1), Envanter no: 1688, Ağız Çapı: 15 cm, Dip Çapı: $7,6 \mathrm{~cm}$, Yükseklik: $5 \mathrm{~cm}$

Döküm tekniğindeki dudaklı eser, yarım küre şeklinde, ortası göbekli ve altı kısa kaidelidir (Bkz. Foto. 8a-b). Tasın dibinde bulunan göbek yukarıya doğru konik çatılıdır. Tasın dıştan dip kısmı taban içe doğru basık formdadır.

Dudakta Fatiha suresine yer verilmiştir. Kabın iç tarafının ağız kısmında tam olarak seçilemeyen harf ve sayılardan oluşan dar bir bordür mevcuttur. Hemen bu bordürün altında içten karın kısmında geniş bir bordür yer almaktadır. Geniş bordür içinde 16 adet dilimli kaş kemer mevcuttur. Kemerlerin içinde 4 satır halinde İhlas, Felak ve Nas surelerinin bir kısmı okunabilmiştir. Tekrar şeklinde yazılmış yazıların bir kısmı oksitlenmelere bağlı oluşan tahribattan dolayı okunamadı. Karın kısmındaki geniş bordürün altında, basit şekilde tasvir edilmiş bezeklerden oluşan dar bir bordür daha bulunmaktadır. Tastaki göbeğin etrafını çevreleyen bordürün içi Arapça harfler ile geometrik şekillerden oluşan tılsımlar bulunmaktadır. Göbek üzeri sade bırakılmıştır. Göbeğin yan yüzeylerinde ise basit kazımalardan meydana gelen 3 adet bordür mevcuttur.

Arka yüzün dudak bölümünde bir sıra halinde "// " şeklinde bezeklenmiştir. Ağız kenarında dar bir bordür içinde basit şekilde tasvir edilmiş kazıma tekniğinde bezekler mevcuttur. Tasın diş karın kısmında geniş bir bordür yer almaktadır. Bordürün içinde bir dizi dilimli kaş kemer bulunmaktadır. Kaş kemerli motifin içinde üç satır halinde besmeleyle başlayan İhlas, Felak ve Nas sureleri ile peygambere salavat şeklinde Allâhümme sallî 'alâ Muhammedin (ve) 'alâ Alihi yazısı yer almaktadır. Karın kısmındaki geniş bordürün hemen altında dar bir bordür daha bulunmaktadır. Bu bordürün içi de ağız kenarındaki bordürde olduğu gibi basit şekilde işlenmiş bezekler yer almaktadır. Tasın dıştan dip kısmı ve göbek girintisinin iç ve yan yüzeyleri ise sade bırakılmıştır. 


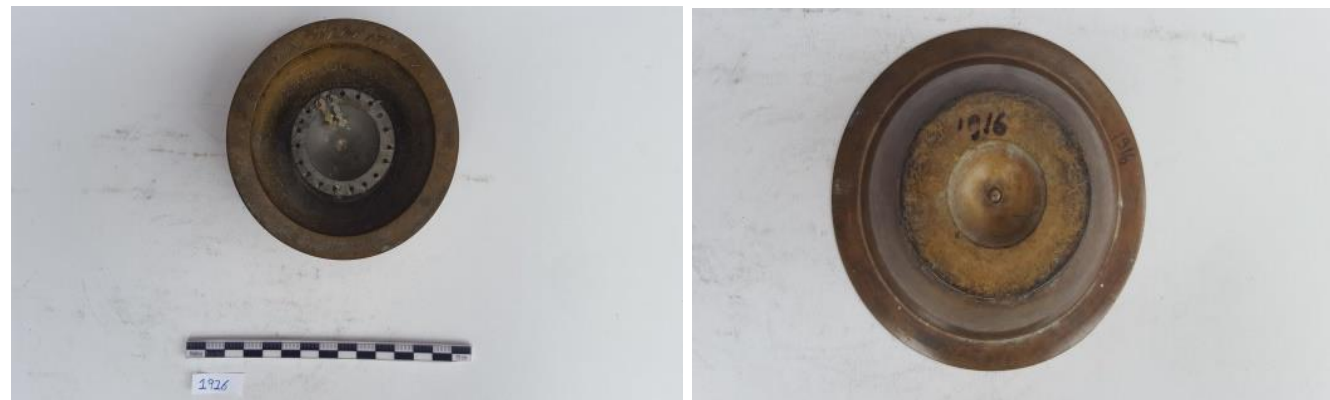

Fotoğraf 9a-b. Pirinç Şifa Tası, Osmanlı (19. yy. sonu), Envanter no: 1916, Ağız Çapı: 11,4 cm, Dip Çapı: 5,8 $\mathrm{cm}$,

Yükseklik: 2,6 cm İç Göbek Çapı: 5,6 cm

Döküm tekniğindeki eser, yayvan yarım küre şeklinde, göbekli ve altı kısa kaidelidir (Bkz. Foto. 9a-b; Çizim 11). Dudaklı tasın ortasındaki göbek üzerine oturtulmuş tasla benzer forma sahip küçük bir tas içten vida ile tutturulmuştur. İçteki küçük tasın dudağ 1 üzerinde simetrik bir şekilde yerleştirilmiş eşit büyüklükte delikler mevcuttur. Bu deliklere anahtar şeklinde plakalar takılmışken ikisi dışında, diğerleri eksiktir.

Dudakta “///" şeklinde kazıma tekniğinde işlenmiş bir friz dolaşmaktadır. İçten karın yüzeyinde Ayete'l-kürsi suresinin tamamı 3 satır halinde düz bir hatla yazılmıştır. Göbek kısmını çevreleyen tasın etrafında "///" şeklinde kazıma tekniğinde işlenmiş küçük bir friz daha bulunmaktadır. Bunların dışında kalan küçük tasın üzerinde herhangi bir süslemeye yer verilmemiştir.

Dışta ağız kısmı ile dış karın yüzeyi dahil kabın tamamı sade olarak bırakılmıştır. Üzerinde herhangi bir süslemeye yer verilmemiştir.
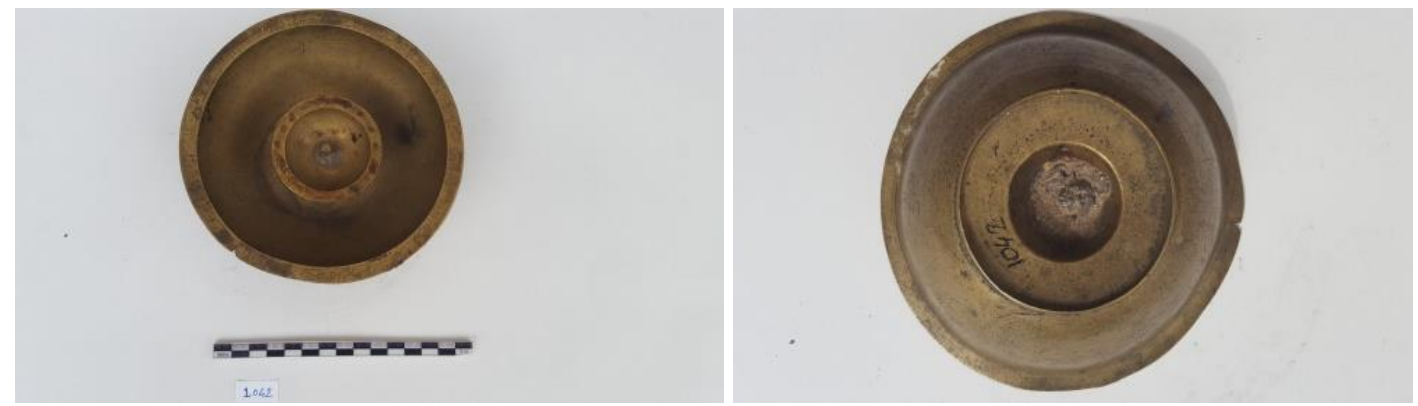

Fotoğraf 10a-b. Bronz Şifa Tası, Osmanlı (19. yy. sonu), Envanter no: 1042, Ağız Çapı: 15 cm, Dip Çapı: 7 cm, Yükseklik: 4,5 cm İç Göbek Çapı: $6 \mathrm{~cm}$

Döküm yapım tekniğindeki eser, yarım küre şeklindedir. Göbekli taslar grubuna giren eserin ortası bombeli ve altı kısa kaidelidir (Bkz. Foto. 10a-b). Kabın ortasındaki göbeği içine alan küçük bir tas içten vida ile tutturulmuştur. İçteki küçük tasın dudaklık bölümünün yüzeyinde, eşit büyüklük ve aralıkta delikler mevcuttur. Deliklere levhacıklar sarkıtılmışken tamamı eksik durumdadır. Dış kısımın dip bölümü ise taban içe doğru basık formdadır.

Dudakta başlayan Yasin suresi, üç satır halinde karın kısmında bulunan 4 adet soğan kubbe motifinin içerisinde devam etmektedir. Soğan kubbe motiflerin araları kazıma tekniğinde basit bezekler ile uçları kıvrık stilize edilmiş yaprak motifleri bulunmaktadır. İçteki küçük tasın delikli dudağı sade bırakılmışken, iç karın kısmında baklava ve yaprak motiflerini andıran basit bezekler mevcuttur. Kabın iç kısmı oldukça süslenmişken dış kısmı ise sade tutulmuştur.

\section{Sonuç, Tartışma ve Öneriler}

Beş Konaklar Etnografya Müzesi’nde toplam 14 adet şifa tası tespit edilmiştir. Gerek Müzedeki enventer kayıtları gerekse de yapılan analizlerde Osmanlı dönemine tarihlenen 14 adet tastan form, 
malzeme ve süsleme kompozisyonları dikkate alınarak, bunlardan mümkün olduğunca birbirinden farklılık gösteren 10 adet eser çalışmaya dahil edilmiştir. Kayıtları tutulan envanter fişlerine göre 10 adet eserden 7 adedi satın alma (Bkz. Foto. 2,5,6,7,8,9,10), geriye kalan 3 adedi de hibe yoluyla müzeye kazandırılmıştır (Bkz. Foto 1,3,4).

Beş konaklar müzesinde ele alınan şifa tasların yapımında kullanılan metalde çeşitlilik olduğu görülmektedir. Çalışmada 6 adetle en fazla bronz alaşımın kullanıldığı görülürken (Bkz. Foto. $5,6,7,8,10$ ), geriye kalan 4 eserden ikisinde bakır (Bkz. Foto 1,2), diğer ikisinde ise pirinç alaşımı kullanılmıştır (Bkz. Foto. 4,9). Form açısından taslar değerlendirildiğinde ana hatlarıyla göbekli ve göbeksiz olmak üzere iki gruba ayırmak mümkündür. Osmanlılar döneminde ilk başlarda göbeksiz olarak kullanılan şifa tasları, 16. yy'den sonra tasın iç dibinde göbek olarak tanımlanan bir bombe yapılmaya başlandı. "Göbekli form tipi Frig döneminde yaygın olarak bronz kaplarıyla benzeşmektedir" (Perk-Paksoy, 2011: s. 10). Göbekli olarak tasarlananlar, göbeğin dış tarafa oyuk /çukur olarak yansımasından dolayı el ile tutulduğunda daha iyi kavranabilmektedir. Bu açıdan kullanıma daha elverişlidir. Bunun yanı sıra tastaki göbeğin kullanımı kolaylaştırma gibi işlevinden ziyade ikonografik bir sembol amac1 güttüğü görüşü, toplumda daha baskın yer edindiği bilinmektedir.

Çalışmada yer alan eserler form açısından iki gruba ayrılmaktadır. Göbeksiz olanlar bu çalışmada en az paya sahip olan kısmı oluşturmaktadır (Bkz. Foto. 1-2). Geriye kalan 8 adet göbekli şifa tasını kendi arasında kabaca iki gruba ayrılır. Tasın iç orta kısmında sade göbek bulunduranlar birinci grubu oluştururken (Bkz. Foto. 3,4,5,6,7,8), göbeğin üzerine tasla benzer forma sahip küçük bir tas bulunduranlar da ikinci grubu oluşturmaktadır (Bkz. Foto. 9a-10a ). İkinci grupta yer alan küçük taslar, asıl tasın iç dip kısmındaki göbek üzerine madeni birleştirme yöntemlerinden vida ya da perçin usulü ile monte edilmiştir. "Bu küçük tasların kenarlarına, göbek kısmına ya da ağız kenarına besmele yazılı, çoğunlukla kırk adetten oluşan pullar sarkıtılırdı" (Perk-Paksoy, 2011, s. 11).

Değerlendirilen Şifa tasları bezeme açısından da bir renkliliğe sahiptir. Tasların iç ve dış yüzeyinde koruduğuna ve iyileştirdiğine inanılan çeşitli ayetler, dualar, Allah'ın güzel isimleri ile 12 imam isimleri gibi kutsallığına inanılan yazılar yer almaktadır. Bunun yanı sıra taslar, tılsımlı düzenlemeler, vefkler, sayılar ve sembollerle de bezenmiştir. Yazılar bazı taslarda bitkisel motiflerin içine istiflenmiştir. Stilize edilmiş damla, şemse ve palmet motifleri bu taslar üzerinde kazıma tekniğinde işlenmiştir (Bkz. Foto. 2,5,6,7). Öte yandan taslar üzerinde kimi mimari öğelerden de bazı motifler görülmektedir. Sivri ve dilimli kaş kemerli motifler kutsal yazıların istif edilmesinde kullanılan en sık motiflerden bir diğeridir (Bkz. Foto. 4,6,7,8). Bunun yanı sira bir eserin göbek üstündeki düz dairesel alanda çark-1 felek motifi görülürken (Bkz. Foto. 3), bir eserin dıştan taban bölümünün iç kısmında mührü Süleyman motifi yer almaktadır (Bkz. Foto. 4). Kullanılan motifler açısından zenginlik gösteren tasların birinde de Yasin suresinin bir kısmının istiflenmesinde kullanılan 4 adet stilize edilmiş soğan kubbe motifi yer almaktadır (Bkz. Foto. 10). Sıkça kullanılan bir diğer motif de madalyonlardır (Bkz. Foto. 3,4,6). Bezeme açısından eserler genel olarak değerlendirildiğinde 10 adet eserden 8 tanesi hem içten hem de dıştan yazı ve diğer motiflerle süslenmişken, Foto. 9-10'da gösterilen eserlerin dış yüzü tamamen sade bırakılmıştır.

İslami dönem şifa taslarının en erken örneklerinin 12. yüzyıla ait Büyük Selçuklulardan kaldığından bahsedilmişti. Ele alınan taslarla paralellik gösteren şifa taslarını diğer müzelerin etnografik salonlarında da görmek mümkündür. Çalışmaya dâhil edilen hamam tası formundaki 2 göbeksiz (Bkz. Foto. 1,2) eserle benzeşen iki adet örnek Haluk Perk koleksiyonu (Perk-Paksoy, 2011, 61) ile Ankara Etnografya Müzesi'nde bulunmaktadır (Ak1, 2013, s. 250). Göbeksiz olarak tasarlanan küt dudaklı 3 örnek, yayvan karınlı form yapılarıyla birbirine benzeşirken süsleme programlarıly birbirinden ayrilmaktadır. 


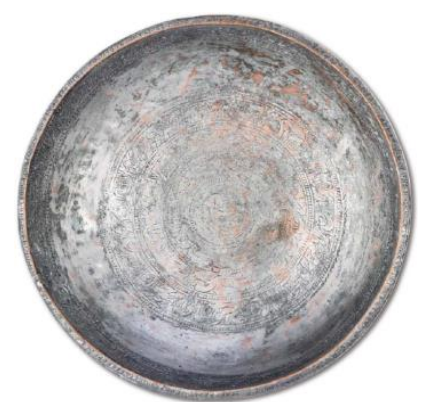

Fotoğraf 11. Bakır Şifa Tası, Haluk Perk Koleksiyonu.

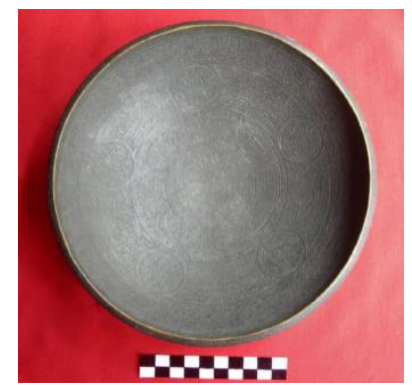

Fotoğraf 12. Bronz Şifa Tası, Ankara Etnografya Müzesi, Envanter no: 10078, (A. Ak1'dan)

Ele alınan göbekli eserlerden foto. 4a-b'de gösterilen bir tasla form açısından benzerlik gösteren iki eser, Konya Etnografya Müzesi (Emiroğlo, 2010, s. 117) ile Ankara Etnografya müzesinde (Ak1, 2013, 207) bulunmaktadır (Bkz. Foto. 11-12). Her 3 eserin de iç yüzeyi yayvan ve göbeklidir. Dip bölümünde bulunan göbeklerin 3 örnekte de kesik konik şeklinde oldukları görülmektedir. Form açısından paralellik gösteren eserler, süsleme düzenlemeleriyle birbirinden farklılık göstermektedir.

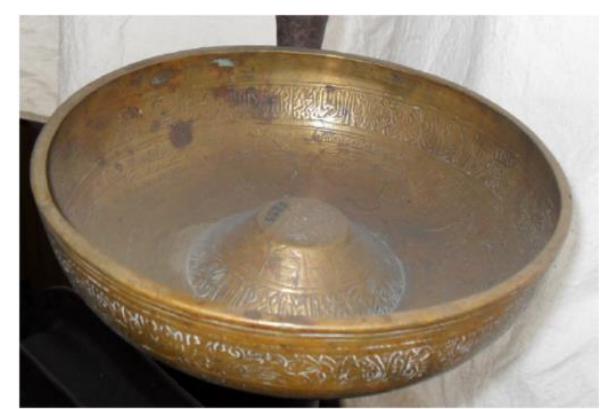

Fotoraf 13. Pirinç Şifa Tası, Konya Etnografya Müzesi, Envanter no:5225, (İ.Emiroğlu’dan)

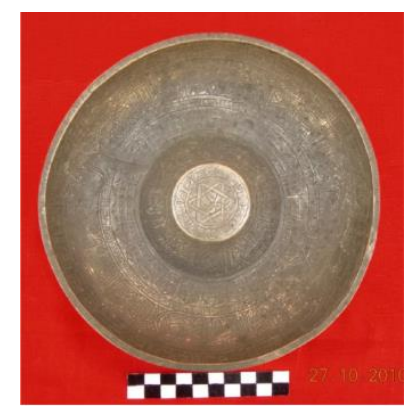

Fotoğrf 14. Bakır Şifa Tası, Ankara Etnografya Müzesi, Envanter no: 240, (A. Akı'dan)

Biçimsel olarak örtüşen eserler dışında, süsleme açısından da Anadolu'nun farklı bölgelerinde üretilen taslar birbirleriyle benzeşmektedir. Foto. 6 ve 15 'te gösterilen eserle bezeme açısından benzerlik gösteren bir tas, Foto. 16 numarasıyla gösterilen Ankara Etnografya Müzesi'nde bulunmaktadır (Ak1, 2013, 233). Her iki eser üzerinde, eserlerin iç karın yüzeyinde sıralı olarak aynı büyüklükte ve iç 
kısımları kutsal yazılarla dolgulanmış dilimli kaş kemer motifleri art arda sıralanmıştır. Bunun yanı sıra, iki eserin de dış karın kısımlarında, içi kutsal yazılarla istiflenmiş madalyonlar mevcuttur.

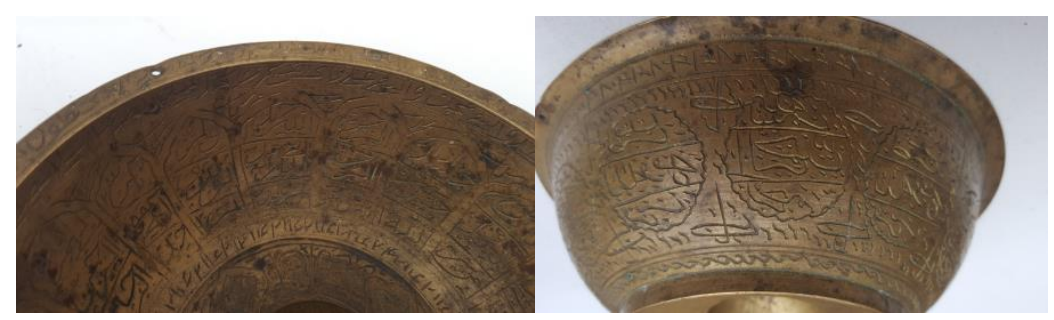

Fotoğraf 15. Çalışmaya Dâhil Edilen Tas. Envanter no:1386

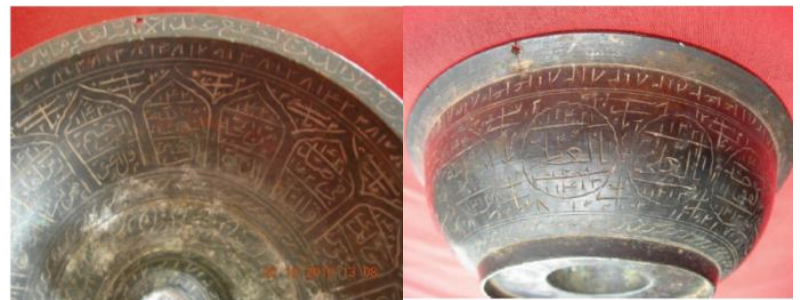

Fotoğraf 16. Bronz Şifa Tası, Ankara Etnografya Müzesi, Envanter no:22882, (A. Ak1'dan)

Geleneksel el sanatları içerisinde hammaddesi metal olanlar grubunda bulunan şifa tasları, ortaya çıktığı dönemin el becerileri yetenekleri ile inanç anlayışını gösteren, üzerinde yer alan yazılar ve süslemeler ile birer sanat eserleridirler. Dolayısıyla Taslar ait oldukları dönemin din ve dine bakış açısını bir yandan gözler önüne sererken, bir yandan da sanat da gelinen noktayı belgelemektedir.

Konuyla ilgili yapılan araştırma ve incelemelerde ele alınan ve müzelerde bulunan şifa taslarının çoğu henüz tanıtılıp yayımlanmadığı anlaşılmıştır. Bu itibarla kültür öğelerimizi oluşturan bileşenlerden biri olan şifa tasları ile ilgili çalışmaların yaygınlaştırılması, Türk ve İslam sanatının tasvir edilmesi noktasında önemli bir etmen olacaktır. Sonuç ve tartışma kısmında da görüldüğü üzere Anadolu'nun pek çok yerinde üretilen şifa taslarının büyük oranda benzer üslup ve amaçlarla oluşturulduğu düşünülürse, Tarih boyunca Anadolu'da yaşayan halkların ortak değerlere sahip olduğu ve aynı kültürden beslendiği görülmektedir.

Anadolu Türk ve İslam dönemine ait kültürel kimliğin oluşmasında önemli bir veri olan şifa tasları, Sanat Tarihi alanında çok az yer kapladığı analizlerden anlaşılmıştır. Sanat Tarihi bilim dünyasında kendisine çok az yer bulan şifa taslarıyla ilgili çalışmaların artırılması, Anadolu Türk ve İslam dünyası için büyük önem arz etmektedir. Dolayısıyla bu çalışma daha sonra yapılacak araştırmalar için ilham ve kaynak olacağına inanılmaktadır. 


\section{Kaynaklar}

Akçadağ, G. (2016). Malatya şehir adı ve şehrin tarihi süreçleri. Akra Kültür Sanat ve Edebiyat Dergisi, (9), 189. https://dergipark.org.tr/download/issue-full- file/29978 internet adresinden, 10 Mayıs 2019 tarihinde erişilmiştir.

Ak1, A. (2013). Ankara Etnografya Müzesi'ndeki şifa tasları. Yüksek Lisans Tezi, Gazi Üniversitesi, Ankara.

Bingöl, F. R. I. (1999). Anadolu Medeniyetler Müzesi, antik takılar. Ankara: Kültür Bakanlığı Yayınları.

Develioğlu, F. (1998). Osmanlıca-Türkçe ansiklopedik lügat, Ankara: Aydın Kitabevi Yayınları.

Emiroğlu, İ. (2010). Konya'da hamam kültürü ve kullanım eşyaları. Yayımlanmamış Yüksek Lisans Tezi, Selçuk Üniversitesi, Ankara.

Gedük, S. (2017). Suyun iyileştirici gücü, şifa kapları. Kültür, Sanat, Şehir, Mevsimlik Tematik Dergi, Güz(2), 358-359. https://zdergisi.istanbul/media/magazines/pdf/Z2-small_EoczDc5.pdf internet adresinden, 20 Mayıs 2019 tarihinde erişilmiştir.

Portakal, R. (2000). Taşlar ve simgeleri. P, Sanat Kültür Antika Dergisi, (17), 133-135.

Perk, H. ve Paksoy, İ. G. (2011). Duanın sudaki gizemi şifa tasları Haluk Perk koleksiyonu. İstanbul: Zeytinburnu Belediyesi Yayınları.

Tali, Ş. (2013). Kayseri Etnografya Müzesi'nde bulunan şifa tasları ve sanatı üzerine. Turkish Studies International Periodical for the Languages, Literature and History of Turkish orTurkic Volume 8(8), 2120-2122. Doi: http://dx.doi.org/10.7827/ TurkishStudies.5176

Topçu, E. (2010). Şifa taslarının Türk tıp folklorundaki yeri, Sağlık Düşüncesi ve Tıp Kültürü Dergisi, Eylül, Ekim, Kasım, (16), 88-92.

Masaracı, Y. (2007). İnanç dünyamızın gizemli objeleri. İstanbul Büyükşehir Belediyesi Sanat ve Meslek $\begin{array}{lllll}\text { Eğitimi Kurslarl (ISMEK) El Sanatlarl Dergisi, } & \text { (4), }\end{array}$ http://ismek.ist/files/ismekOrg/File/ekitap/el_sanatlari/dergi4.pdf internet adresinden, 15 Haziran 2019 tarihinde erişilmiştir.

Sözen, M. ve Tanyeli U. (2014). Sanat kavram ve terimleri sözlüğ̈̈. İstanbul: Remzi Kitapevi Yayınları. 


\section{Ekler}

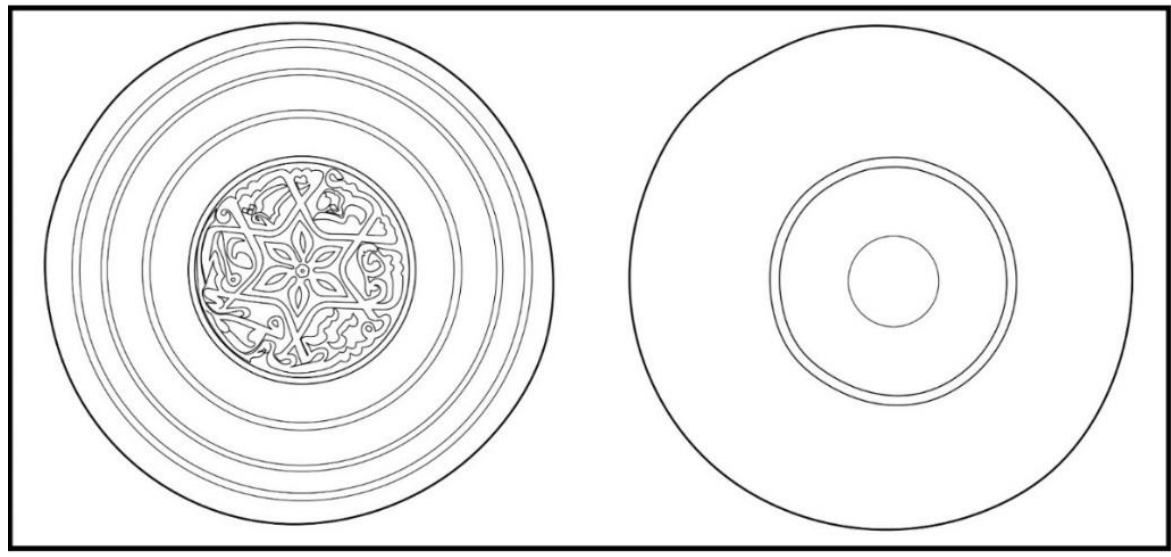

Çizim 1

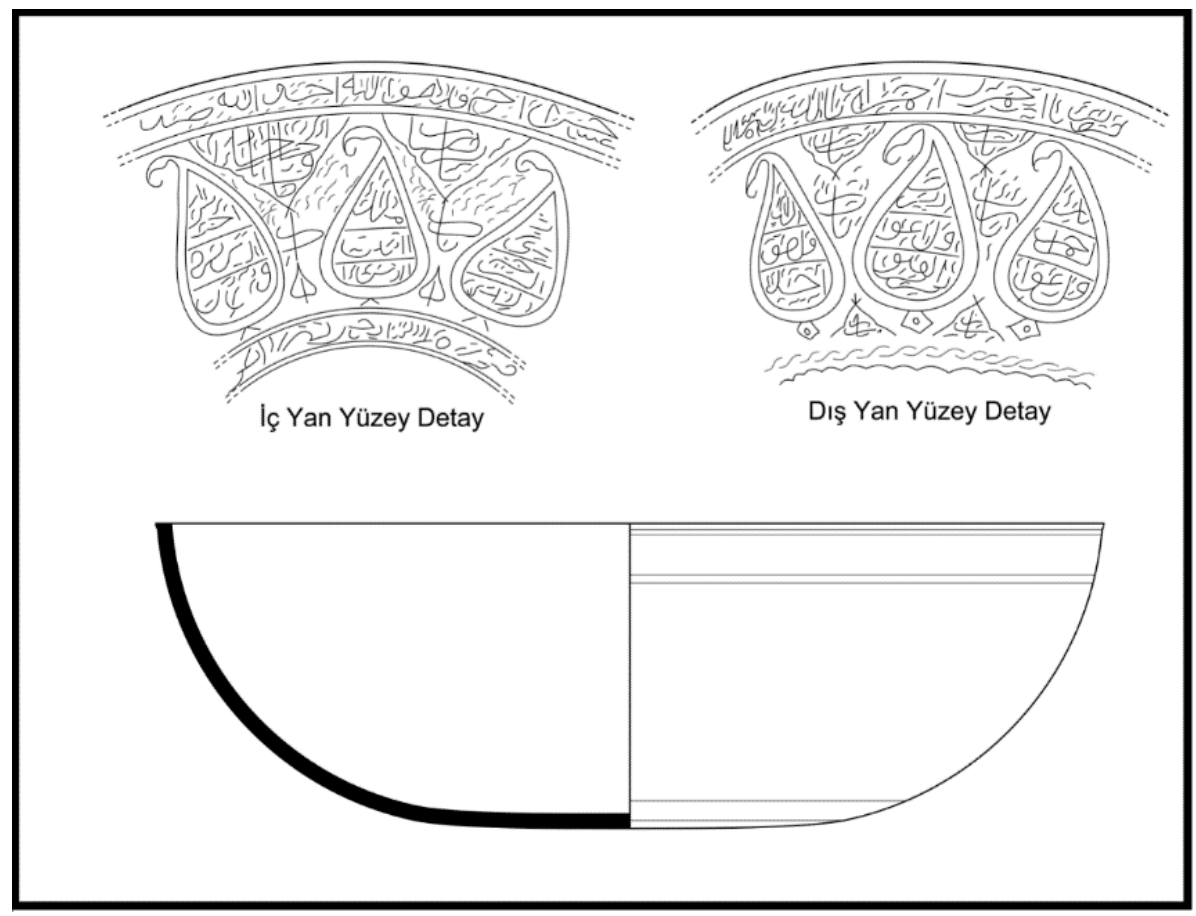

Çizim 2 


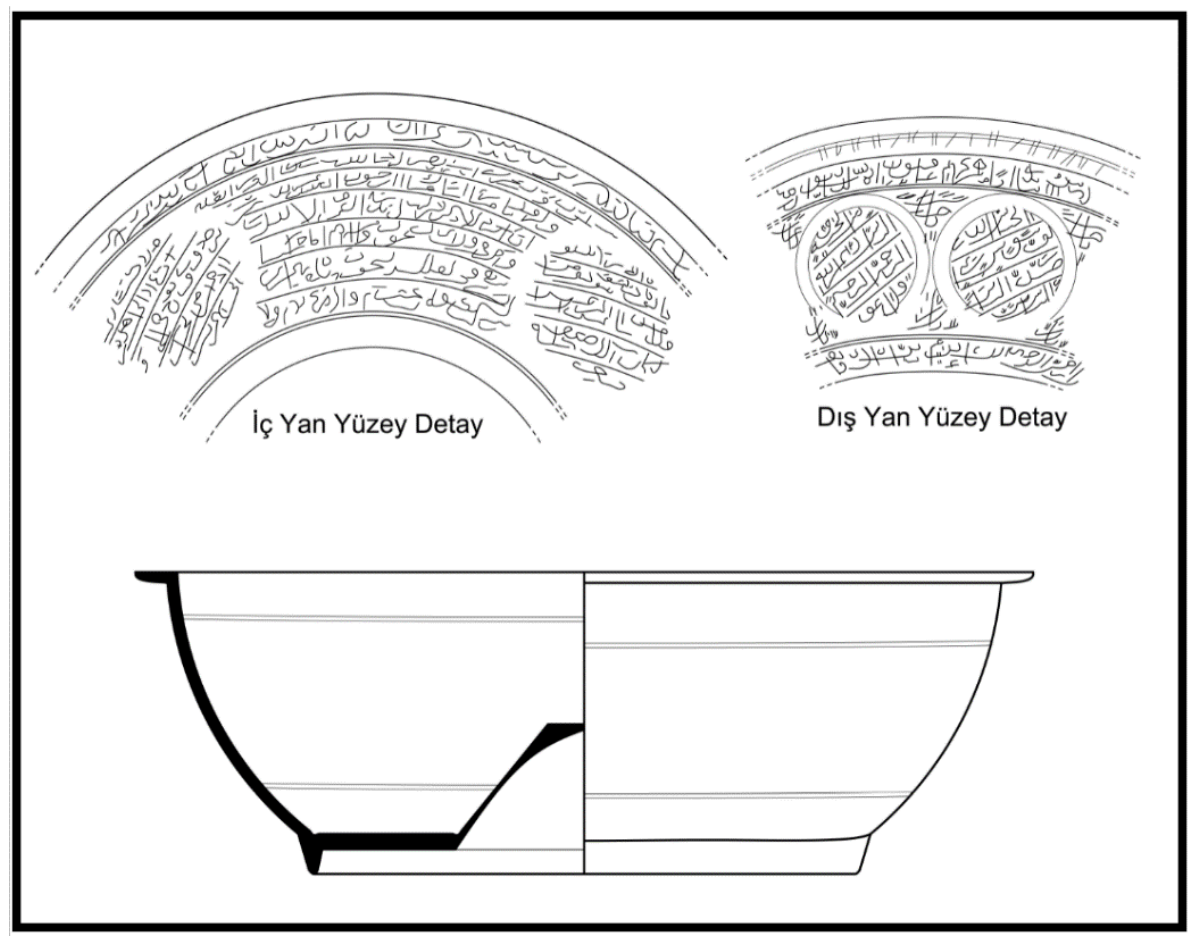

Çizim 3

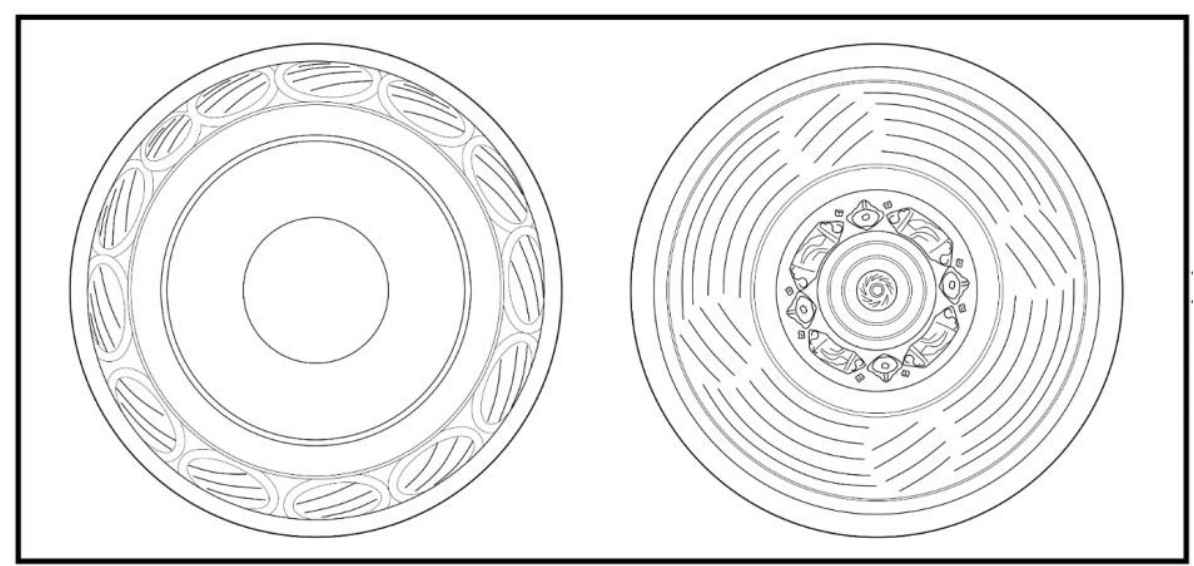

Çizim 4

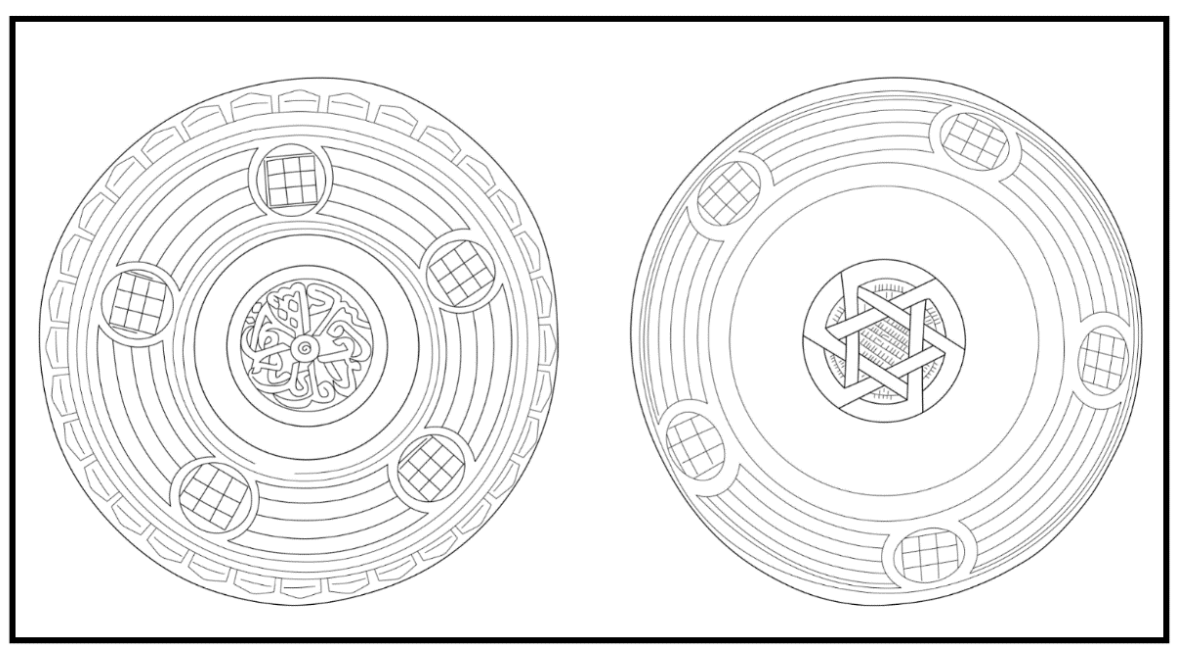

Çizim 5 

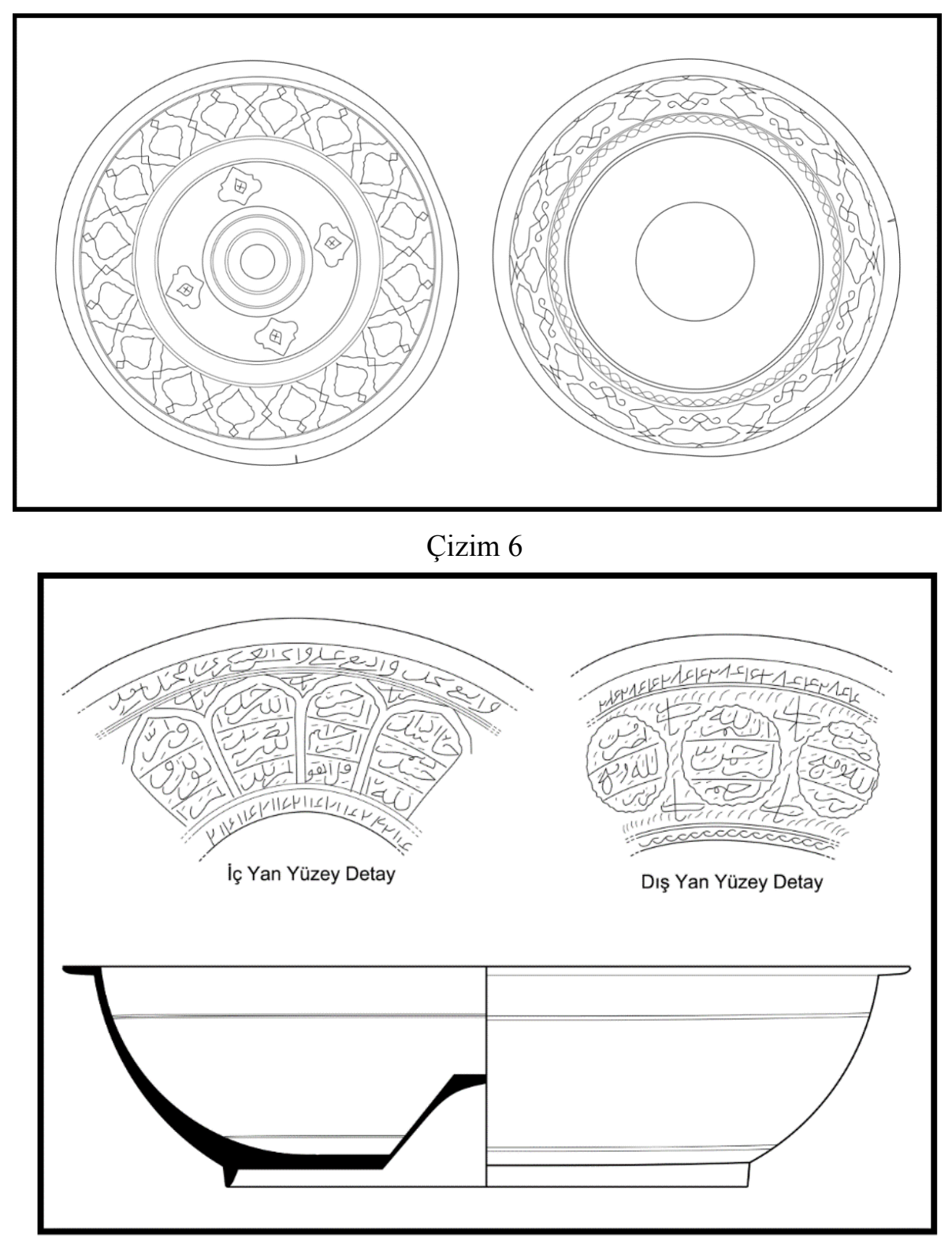

Çizim 7

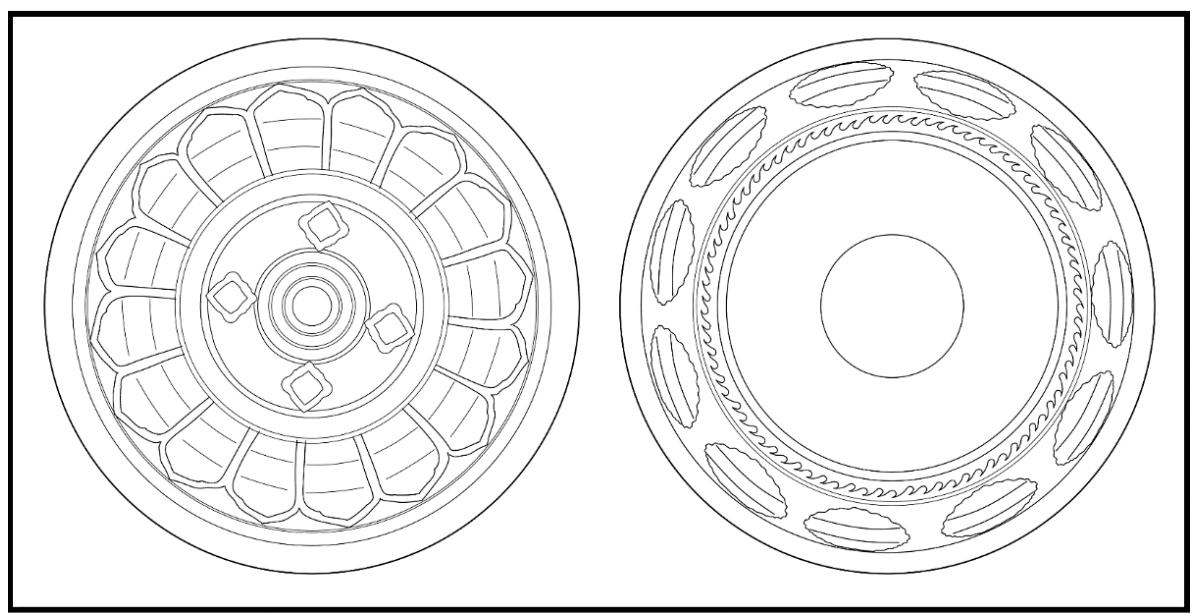

Çizim 8 


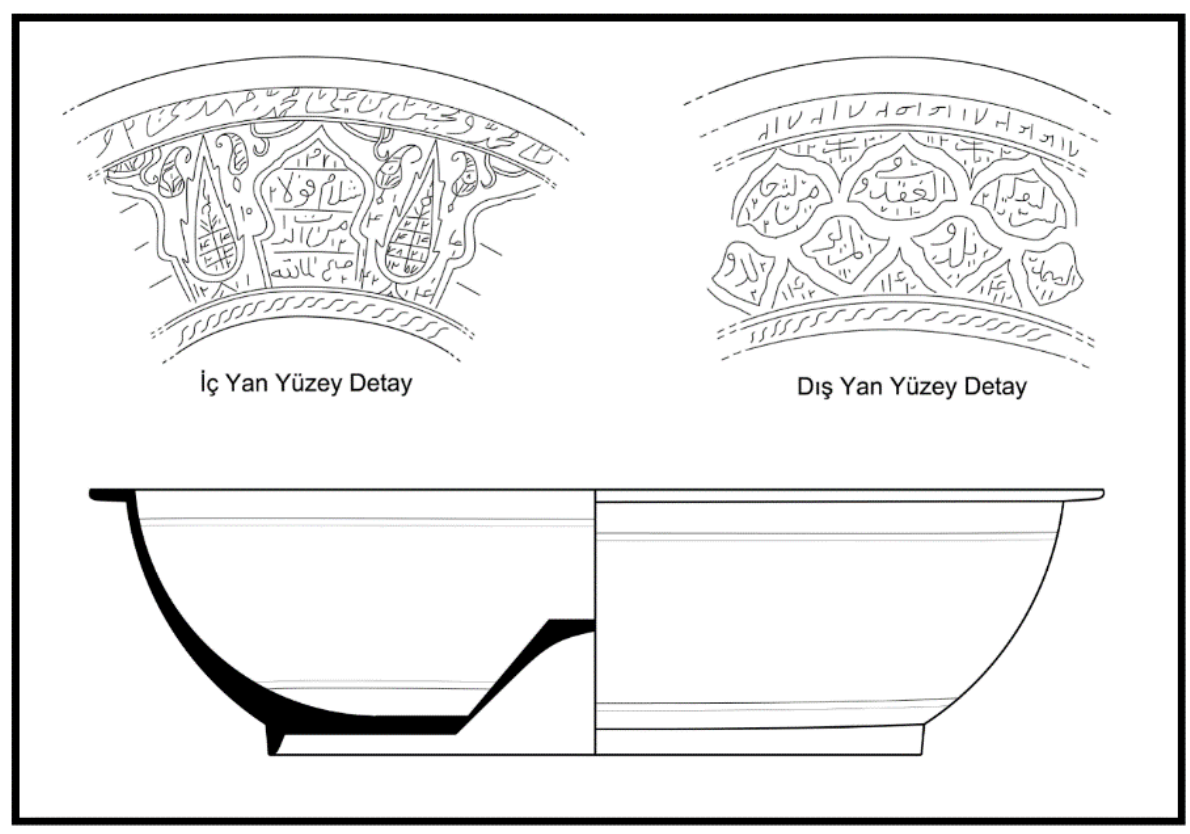

Çizim 9

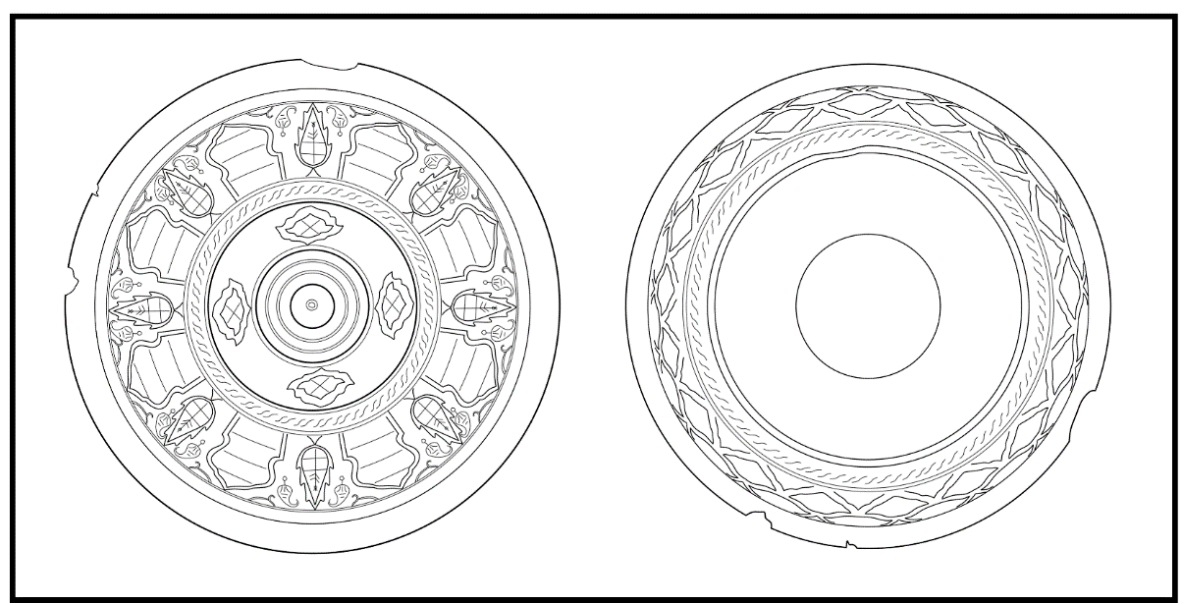

Çizim 10

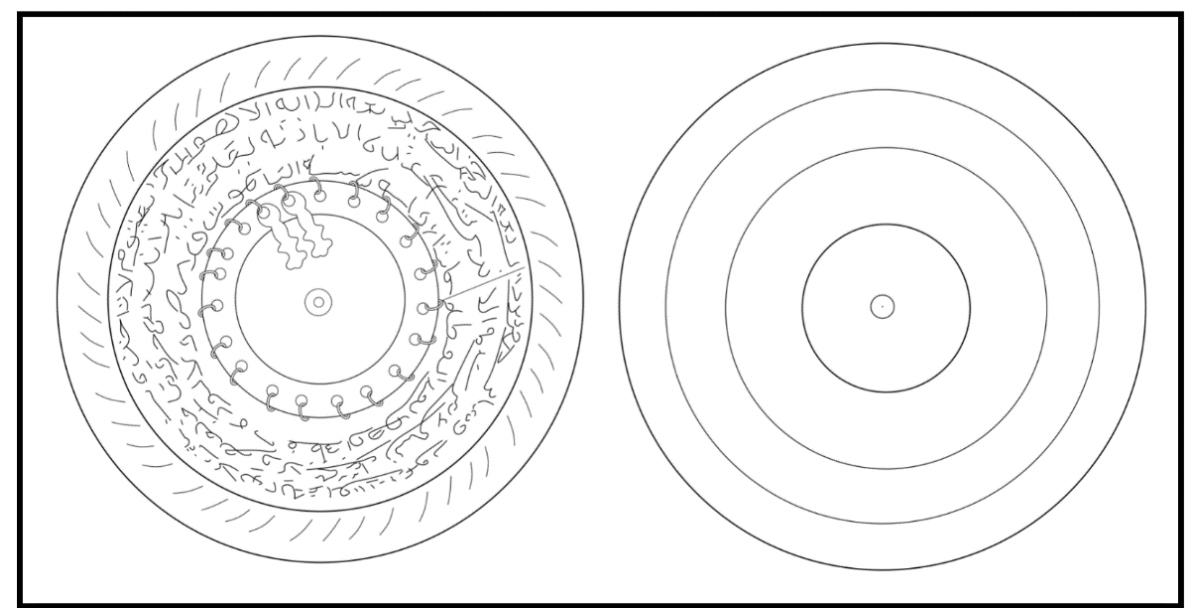

Çizim 11 


\section{Extended Abstract}

\section{Introduction}

Malatya is a city which has been located in a geopolitical site considered important throughout the ages. It is located in the Yukarı Firat basin of Eastern Anatolia Region of our country. The city, which has hosted many civilizations, is of the most important historical cities of Anatolia. The artifacts that were brought to light with the excavations carried out in some settlements dating back to prehistoric periods, and that were obtained through the citizens in some way are exhibited and preserved in museums located in the city. The healing bowls included in the study are kept in Beşkonaklar Ethnography Museum located in the city.

It is known that healing (şifa) has been practiced by people from past to present for the purposes of treating a disease and healing the patient. The term şifa (healing) grounded to Arabic has been used in the meanings such as treatment. Şifa, which means purifying spiritually and physically from pollution, evil and diseases, has been tried to be conveyed based on the beliefs of different societies that lived in every period of history and by various means and mostly with water which is the most basic necessity of human life. These bowls through which the healing is conveyed with water and made in various forms on which there are Arabic letters, verses of the Qur'an, prophetic hadiths, amulets, numbers, are called " healing bowl".

Healing bowls are important ethnographic artifacts that document the art and socio-cultural structure of the societies that lived in the past. Throughout history, people have been in quest of spiritual and physical health. One of them is the medical path, while the other is the religion which is observed in every society as a common symptom of all societies and the sacred books which subsist within this framework. In the present study, the healing bowls, as one of the tools used to recover from mental and physical illnesses, are discussed. In fact, in addition to reflecting the artistic features of the period to which it belongs, the healing bowls reveal the people's religion and religious views. In the present study, the socio-cultural and artistic understanding of the period was tried to be investigated by addressing 10 bowls at the Malatya Beşkonaklar Ethnography Museum.

\section{Method}

In the selection of the bowls included in the study, it was seen that there is very limited research carried out in this field. Upon obtaining the necessary permissions from the relevant museum, all the bowls in the museum were reviewed. Among the healing bowl group of 14 pieces, 10 vessels, which were detected to be different from each other in terms of form, material and ornamental compositions, were evaluated. It was determined which construction and decoration techniques were used together with the material used in the construction in the first place, by examining the bowls on-site. After the sizes of the artifacts were measured, the analysis of the sacred scriptures on them has started to be done. Then, the artifacts were promoted by making their drawings. After the art features of the works were determined, comparisons were made with similar bowls produced in different regions of Anatolia and found in different museums. By drawing conclusions about the artifacts whose evaluation periods are completed, it is tried to emphasize the meaning and value of healing bowls for the present day with their adventures in the Turkish and Islamic world.

\section{Results and Discussion}

Ten of the 14 healing bowls detected in Beş Konaklar Ethnography Museum were evaluated and introduced. According to the inventory records in the museum, 7 of the artifacts were purchased and the remaining 3 were contributed to the museum through donations. In the present study, the artifacts were tried to be introduced by addressing them from various perspectives. The bowls, which were discussed in terms of form, decoration, material and technique, were found to have rich variety in every aspect. In terms of form, the splay hemispherical artifacts are generally divided into two groups, as with and without a core. 8 of them are designed with a core and 2 of them are without a core. Healing bowls 
have also variegation in terms of decoration. The inner and outer surfaces of the bowls are decorated with talismanic arrangements, numbers, symbols and plant-based and architectural elements along with sacred scriptures.

Most of the bowls addressed here and found in other museums do not have a date on them. Therefore, the issue of the dating of the artifacts is controversial. However, the decoration programs and other writings on the bowls have strengthened the possibility of belonging to the 19th-century Ottoman period.

\section{Recommendations}

It is very important, for Anatolian Turkish and Islamic world, to increase the works on the healing bowls, which find very little place in the field of the Art History. Therefore, with the spread of such works, the picture of Turkish Islamic culture and art will become clearer. 